\title{
Traditional Foods and Sustainable Rural Development: Exploiting the Case of the Comoros Tea as a Potential Source of Bioactive Compounds
}

\author{
Dario Donno ${ }^{1, * \mathbb{C}}$, Saandia Hassani ${ }^{2}$, Toilibou Sofoini ${ }^{3}$, Maria Gabriella Mellano ${ }^{1}$, Isidoro Riondato ${ }^{1}$, \\ Giovanni Gamba ${ }^{1}$ and Gabriele Loris Beccaro ${ }^{1}$ \\ 1 Department of Agricultural, Forest and Food Sciences, University of Turin, 10095 Turin, Italy; \\ gabriella.mellano@unito.it (M.G.M.); isidoro.riondato@unito.it (I.R.); giovanni.gamba@unito.it (G.G.); \\ gabriele.beccaro@unito.it (G.L.B.) \\ 2 National School of Cooking and Application-CODCOM, Moroni 167, Comoros; saandiacodcom@gmail.com \\ 3 Department of Sciences and technologies, University of the Comoros, Moroni 167, Comoros; \\ toilibousoifoini@yahoo.fr \\ * Correspondence: dario.donno@unito.it; Tel.: +39-011-670-8751
}

check for

updates

Citation: Donno, D.; Hassani, S.; Sofoini, T.; Mellano, M.G.; Riondato,

I.; Gamba, G.; Beccaro, G.L.

Traditional Foods and Sustainable Rural Development: Exploiting the Case of the Comoros Tea as a Potential Source of Bioactive Compounds. Sustainability 2021, 13, 5815. https://doi.org/10.3390/ su13115815

Academic Editor: Marc A. Rosen

Received: 28 April 2021

Accepted: 14 May 2021

Published: 21 May 2021

Publisher's Note: MDPI stays neutral with regard to jurisdictional claims in published maps and institutional affiliations.

Copyright: (c) 2021 by the authors. Licensee MDPI, Basel, Switzerland. This article is an open access article distributed under the terms and conditions of the Creative Commons Attribution (CC BY) license (https:/ / creativecommons.org/licenses/by/ $4.0 /)$.

\begin{abstract}
Although modern medicine is available in many developing countries, such as the Comoros Islands, the primary health-care needs of the local population are based on traditional foods and beverages derived from natural resources and medicinal plants for cultural and historical reasons. Aphloia theiformis (Vahl) Benn. ('Mfandrabo'), Cinnamomum verum J.Presl ('Mani yamdrara'), Ocimum gratissimum L. ('Roulé'), Plectranthus amboinicus (Lour.) Spreng. ('Ynadombwe'), Cymbopogon nardus (L.) Rendle ('Sandze monach') and Ocimum americanum L. ('Kandza') are six wild plants that are largely utilised to treat many diseases. The leaves of these plants are used in the traditional Comorian tea (aqueous infusion). This study aimed to identify and quantify the main health-promoting compounds in the traditional formulation of Comorian tea by HPLC profiling together with a preliminary assessment of antioxidant capacity to confirm the traditional use of these plants by the local population. The single plants were also studied. The Comoros tea presented a total polyphenolic content (TPC) of $4511.50 \pm 74.41 \mathrm{mg}_{\mathrm{GAE}} / 100 \mathrm{~g}$ DW, a value higher than the TPCs of the different plants included in the Comorian tea. Moreover, the Comorian tea showed an antioxidant capacity

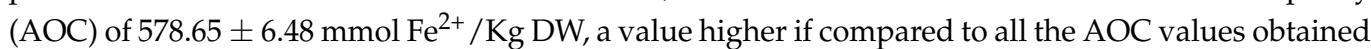
in the single plants. The polyphenolic fraction $(771.37 \pm 35.76 \mathrm{mg} / 100 \mathrm{~g} \mathrm{DW})$ and organic acids $(981.40 \pm 38.38 \mathrm{mg} / 100 \mathrm{~g} \mathrm{DW})$ were the most important phytochemical classes in the Comorian tea $(40.68 \%$ and $51.75 \%$ of the total phytocomplex, respectively), followed by the monoterpenes $(5.88 \%)$ and vitamin C (1.67\%), while carotenoids were detected in trace $(0.02 \%)$. The Comorian tea could be important in meeting the high demand in the Comoros Islands and other developing countries for cost-effective and natural health-promoting foods and/or beverages to be produced by agri-food industries and used by the local population. This study may promote traditional foods in rural communities in the Comoros Islands and contribute to sustainable rural development and a commercial valorisation of these plants for health-promoting and food applications.
\end{abstract}

Keywords: traditional herbal tea; Comoros Islands; phenolic compounds; antioxidants; HPLC; agrobiodiversity; sustainable use of natural resources

\section{Introduction}

Natural resources are utilised extensively by food and pharmaceutical industries to develop, synthesise, and produce functional foods, drugs, fragrances, food supplements, and cosmetics. Indeed, many licensed foods and drugs (about 40\%) are derived from plants [1]. Medicinal plants are the most important materials for traditional food and medicine, and more than 3.3 billion people in developing countries regularly use medicinal 
plants [2]. During the last decade, traditional health-promoting systems have become a topic of global importance. The worldwide plant food and herbal drug markets are increasing, and they are estimated to be about $\$ 60$ billion/year (7\% of annual growth) [3].

Although modern medicine is available in many developing countries, such as the Comoros Islands, the primary healthcare needs of the local population are based on traditional foods and beverages derived from natural resources and medicinal plants for cultural and historical reasons. The main challenge for commercial food and herbal companies is now to meet the increasing demand for natural resources and relative derived products because they can provide employment and encourage exports in developing countries poor in other resources, like minerals or oils [4]. Even if plants provide opportunities to quickly obtain profits thanks to their harvesting and selling, large-scale deforestation and absence of regulation in plant cultivation and use may contribute towards unsustainable health-promoting plant utilisation. Moreover, although indigenous plants are very important for livelihoods and health, few economic resources have been invested to assess their conservation status or to develop effective tools for ensuring more sustainable and equitable plant utilisation practices. For this reason, governments, as well as local, regional and international companies, should be encouraged to study new sustainable approaches to help resource managers, collectors, industry and other stakeholders [5]. Indeed, production and processing of natural resources and plants may be an interesting opportunity for small and medium enterprises (SME) as they do not require huge investments (capitals or machinery) and may also be environmentally friendly [3].

Comoros is an archipelago composed of four islands located in the Mozambique Channel, between the African coast and north-western Madagascar, about $300 \mathrm{~km}$ off the eastern coast of Africa. The islands from northwest to southeast include Grande Comore (N'gazidja), Mohéli (Mwali), Anjouan (Ndzuwani), and Mayotte (Mahore) [6]. Its plant biodiversity is estimated at more than 2000 species. In the last decades, rapid deforestation caused mainly by domestic firewood consumption reduced the islands' forested land, and now about one-sixth of the land remains covered with forests [7]. In any case, aromatic and medicinal plants (e.g., frangipani, jasmine and lemongrass) strongly characterise these islands [8].

In Comoros, most of the population (more than two-thirds) currently live in rural areas with an economy based on subsistence fishing and agriculture. A lack of good health infrastructure, infant mortality, poverty and no access to the modern healthcare and food security system are the main issues for the Comorian population. Less than half of the population has access to safe drinking water, and parasitic infestation is prevalent. Other serious illnesses are malaria, cholera, tuberculosis and, to a lesser extent, leprosy and AIDS [9]. For centuries, they have formed and based their health-care system on healers, natural products and traditional medicine derived from African Bantu and ArabMuslim medicine and culture [6,10], even though little written information exists about the traditional medicinal plants used.

Aphloia theiformis (Vahl) Benn. ('Mfandrabo'), Cinnamomum verum J. Presl ('Mani yamdrara'), Ocimum gratissimum L. ('Roulé'), Plectranthus amboinicus (Lour.) Spreng. ('Ynadombwe'), Cymbopogon nardus (L.) Rendle ('Sandze monach') and Ocimum americanum L. ('Kandza') are six wild plants [11] that are largely utilised to treat many diseases (e.g., diarrhoea, gynaecological and digestive problems, ulcers, diabetes and intestinal parasites) thanks to their anti-inflammatory, antibacterial, antifungal, antispasmodic and antioxidant properties [12-14]. The leaves of these plants are used in the traditional Comorian tea (aqueous infusion). After the harvest, the leaves of all the plants are washed and mixed by cutting them into small pieces and finally they are spread out on mats for drying to avoid humidity. Normally, about $0.8-1.0 \mathrm{~g}$ for each plant are used. Just after drying, the powder of the mixed dried plants (in total, about $5 \mathrm{~g}$ in $200 \mathrm{~mL}$ of water) is utilised to prepare the Comorian tea $[15,16]$. African, Malagasy and Indian populations contribute to the final Comorian tea formulation thanks to their relative knowledge and experience on medicinal plants and preparation methods (e.g., infusion or decoction). The composition 
of Comorian tea varies depending on the islands in the Comorian archipelago. Sometimes, people prefer a spicier tea (addition of ginger) or a sweeter version (no addition of specific bitter-taste plants such as large thyme and basil). It is also possible to add flowers of other species (e.g., Hibiscus spp. or Jasminum spp.) [17]. However, tea is the second most consumed beverage thanks to its health-promoting properties [18]. Tea's biological activity is mainly due to the synergistic and additive bioactivity of phytochemicals, such as phenolic acids and flavonoids [19]. For this reason, the quantification of total and single bioactive compounds is very important so that they may be correlated with the health-promoting properties of tea.

This study aimed to identify and quantify the main health-promoting compounds in the traditional formulation of Comorian tea by HPLC fingerprinting together with a preliminary assessment of antioxidant capacity to confirm the traditional use of these plants by the local population. Moreover, the identification and quantification of the selected bioactive substances may be useful to support traditional Comorian tea as a potential source of bioactive compounds. This study may promote traditional foods in rural communities in the Comoros Islands and contribute to sustainable rural development and a commercial valorisation of these plants for medicinal and food applications [20].

\section{Materials and Methods}

\subsection{Plant Material}

Eighteen different plant species were harvested for their use in the traditional Comorian food and medicine. Six plants were then selected and analysed for their use in the traditional Comorian tea. For this reason, the investigated material consisted of leaves from six plant species (Figure 1) that constitute the traditional Comorian tea (Aphloia theiformis (Vahl) Benn.-C2, Cinnamomum verum J. Presl-C12, Ocimum gratissimum L.C6, Plectranthus amboinicus (Lour.) Spreng.-C7, Cymbopogon nardus (L.) Rendle C4 and Ocimum americanum L.-C5). Moreover, the leaves of these plants were sun-dried for few days, minced and mixed (about $0.8-1.0 \mathrm{~g}$ of leaves for each plant are used) and an aqueous infusion (in total, about $5 \mathrm{~g}$ in $200 \mathrm{~mL}$ of water at $80{ }^{\circ} \mathrm{C}$ for 10 minutes) has been prepared in accordance with the traditional preparation of the Comoros tea and then analysed. Plant material was collected in 2019 by the local researchers and technicians of the Coopérative et Mutuelle des Comores pour le Développement (CODCOM) in Moroni, Comoros Islands. CODCOM is a non-governmental organisation aimed to reduce poverty in countries of the Indian Ocean such as the Comoros Islands. Plants were identified by Dr Toilibou Soifoini, confirmed by Dr Andilyat Mohamed, and registered at the National Herbarium, University of the Comoros. The voucher numbers for the considered plants are: AND47HKM for Aphloia theiformis (Vahl) Benn; AND509HKM for Cinnamomum verum J. Presl; ADN500HKM for Ocimum gratissimum L.; AND504HKM for Plectranthus amboinicus (Lour.) Spreng.; AND814HKM for Cymbopogon nardus (L.) Rendle; and AND497HKM for Ocimum americanum $\mathrm{L}$. The collected plant material was stored in a dark place at $4{ }^{\circ} \mathrm{C}$ and $95 \%$ R.H. (relative humidity) and then dried before being ground.

\subsection{Analytical Protocols and Methods}

A description of the reagents, chemicals, methods and techniques utilised for bioactive compound extraction and chromatographic analysis of plant material is detailed in the Supplementary Material (Tables S1 and S2). The same analyses were performed on the aqueous infusion and the extracts of single plants. The plant specimens of the same lot were used for all the analyses of the mixture and the individual plants.

\subsubsection{Spectrophotometric Analysis}

The Folin-Ciocalteu method [21,22] was utilised to measure the total polyphenolic content (TPC); results were expressed as milligrams of gallic acid equivalents (GAE) per $100 \mathrm{~g}$ of dried weight (DW). The Ferric Reducing Antioxidant Power (FRAP) assay [23] was used to evaluate the antioxidant capacity (AOC); results were expressed as millimoles 
of ferrous iron $\left(\mathrm{Fe}^{2+}\right)$ equivalents per kilogram of DW. Gallic acid was used to obtain a standard calibration curve (SCC) at a concentration range of $0.02-0.1 \mathrm{mg} / \mathrm{mL}$ for TPC, while $\mathrm{FeSO}_{4} \cdot 7 \mathrm{H}_{2} \mathrm{O}$ was utilised for the SCC at a concentration range of $100-1000 \mathrm{mmol} / \mathrm{L}$ for AOC.

TPC and AOC were evaluated by a UV/Vis single-beam spectrophotometer (1600-PC, VWR International, Milan, Italy).

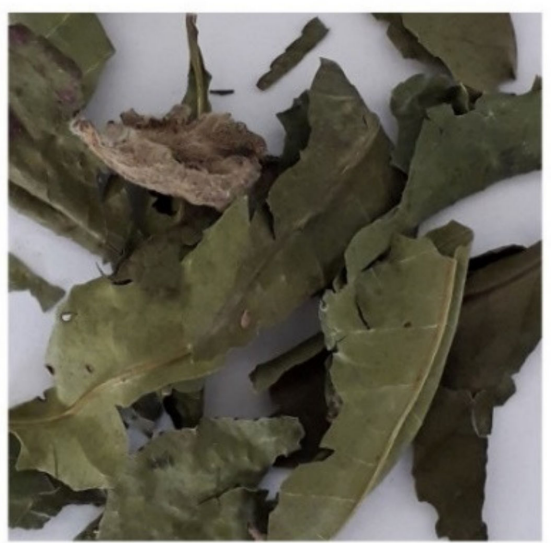

Aphloia theiformis (Vahl) Benn.

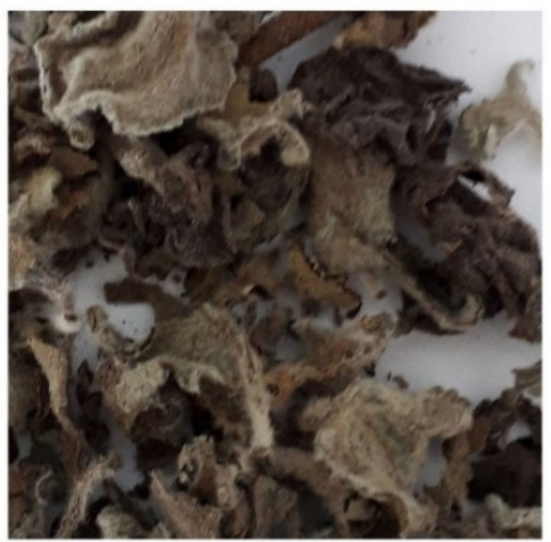

Plectranthus amboinicus (Lour.) Spreng.

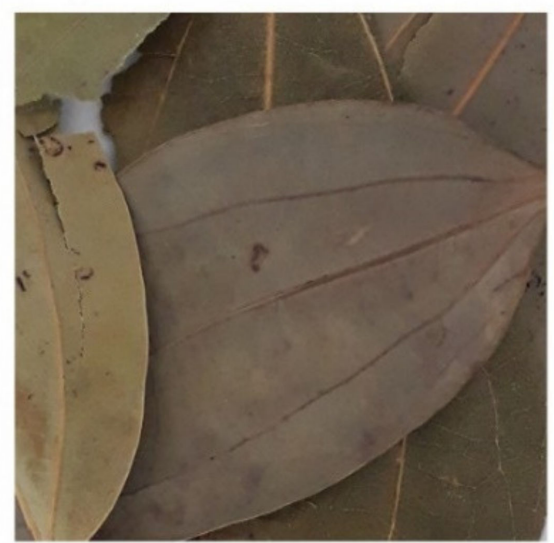

Cinnamomum verum J.Presl

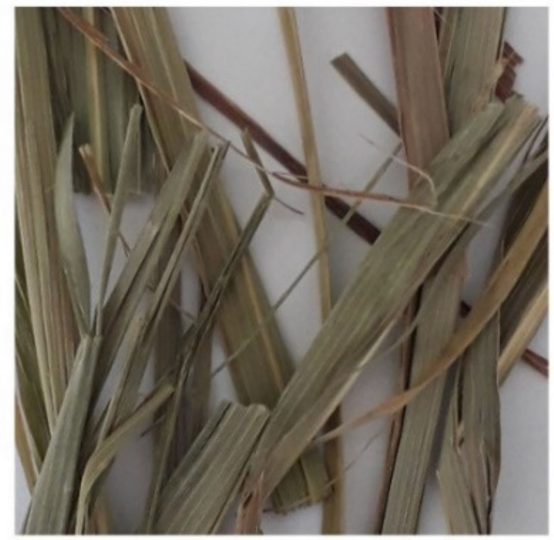

Cymbopogon nardus (L.) Rendle

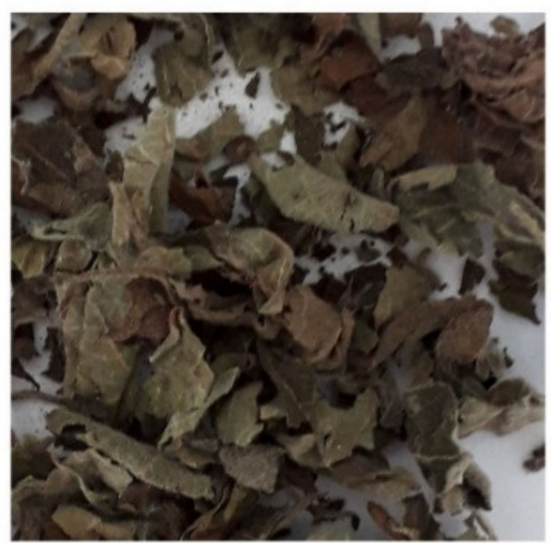

Ocimum gratissimum $\mathrm{L}$.

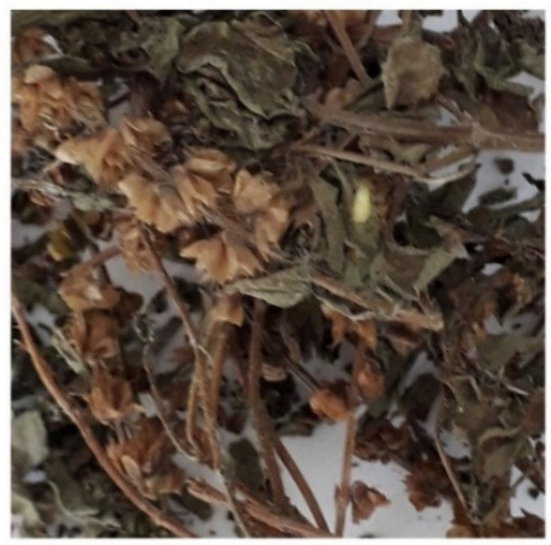

Ocimum americamum $\mathrm{L}$

Figure 1. The leaves of the six plant species used in the traditional Comorian tea.

\subsubsection{Chromatographic Analysis}

The compound separation was carried out by an Agilent 1200 HPLC-UV/Vis Diode Array Detector (Agilent Technologies, Santa Clara, CA, USA).

A Kinetex C18 column $(4.6 \times 150 \mathrm{~mm}, 5 \mu \mathrm{m}$, Phenomenex, Torrance, CA, USA) was utilised to perform the chromatographic separations. Plant material was analysed by several chromatographic protocols, previously described and validated by Donno et al. [24], with some modifications. Identification and quantification of selected peaks were carried out by scanning specific wavelengths from 190 to $600 \mathrm{~nm}$.

This study is preliminary research for the evaluation of phytochemical composition of the Comorian tea. In this study total phytocomplex was considered rather than single specific compounds. For this reason, phytocomplex was evaluated by selecting the most important biomolecules based on literature and comparing spectroscopic data and retention times with authentic external standards following the "multi-marker approach" (MMA) by Mok and Chau [25]. Compounds were selected for their demonstrated synergistic and additive health-promoting activity in humans. Currently, plant material is mainly characterised by evaluating the concentration of few biomarker substances ("marker approach"-MA). Because biological properties are due to the synergistic action of many molecules, the MMA 
used in this study is the natural extension of the MA. It uses many identified biologically active compounds to represent a whole sample in complex systems or matrices. Due to a very high amount of potentially active biomolecules, it is very difficult to estimate all the bioactive compounds; for this reason, the phytocomplex is evaluated as the sum of the most important substances selected for their biological activity. For further studies, it will be important to add more markers and in particular select specific markers for each considered plant that constitute the Comorian tea (e.g., mangiferin in A. theiformis, rosmarinic acid in P. amboinicus, eugenol in C. verum and Ocimum spp.). In this research, the fingerprint evaluation was performed by selecting four polyphenolic classes. Levels of carotenoids, monoterpenes, vitamin C, and organic acids were studied as well. Results were expressed as $\mathrm{mg} / 100 \mathrm{~g}$ of dried weight (DW), except for carotenoids (expressed as $\mu \mathrm{g} / \mathrm{g}$ of DW).

\subsection{Statistical Analysis}

A one-factor ANOVA test was utilised to evaluate data, expressed as mean value \pm standard deviation (SD); the mean values were compared by using Tukey's HSD post-hoc comparison test at $p<0.05(\mathrm{~N}=3)$. Different letters following the Tukey test were used to highlight statistically significant differences $(p<0.05)$. The correlation index was evaluated with Pearson's coefficient (r) at $p<0.05$.

A principal component analysis (PCA) was carried out on a data matrix including 18 rows (three repetitions for six samples) and 10 fields. The PCA was only performed on the extracts of single plants. Such variables included the content of eight chemical classes: CA (cinnamic acids), FL (flavonols), BE (benzoic acids), CAT (catechins), MO (monoterpenes), OA (organic acids), VC (vitamin C), CAR (carotenoids), TPC (total polyphenol content) and AOA (antioxidant activity). A second PCA was performed on a data matrix including the same 18 rows (three repetitions for six samples) and 34 fields. In this case, the selected variables included all the bioactive compounds together with TPC and AOC. The Bartlett's test of sphericity was carried out, and the Kaiser-Meyer-Olkin (KMO) index was calculated from the data matrix $[26,27]$. The two data matrices were centred and column-wise scaled, and then the relative cell values were transformed into Z-scores [28]. Varimax rotation of the principal axes was applied to the data matrices. The number of principal components (PCs) was selected considering at least $50 \%$ of the total variance. The plots with the loadings of all the chemical variables in the PC planes were used to show the association between the selected chemical variables and the obtained PCs [26,27].

All the statistical calculations were carried out by IBM SPSS Statistics 22.0 (IBM, Armonk, NY, USA).

\section{Results and Discussion}

A sustainable rural development is one of the main challenges for the next years. Energy, malnutrition in children, and micronutrient deficiencies (e.g., vitamin deficiency and nutritional anaemias) are important public health issues influencing productivity, intellectual development, and maternal/infant health in rural areas as Comoros Islands, despite an abundance of often underexploited plant species, grown in seminatural conditions, with high health-promoting properties thanks to their bioactive compound composition. The characterization of potential innovative functional foods and their nutritional and nutraceutical traits could be an example of biodiversity integration and conservation to valorise a food production and raise income for the population and the agri-food industry. The advances in food production can be important in poverty reduction and deserve greater attention in sustainable rural development.

For this reason, this research was focused on the evaluation of phytochemical composition of the Comorian tea. Specific extraction solution was prepared to evaluate the effective composition of single plants, while aqueous infusion was used to evaluate the phytochemicals in the traditional beverage used by local population. The analyses on aqueous infusion allowed to determine the quality and the quantity of bioactive compounds that are extracted by population with the traditional tea. This approach may define the po- 
tential for a better nutrition, maintenance of biodiversity, and environmentally sustainable food systems.

\subsection{Antioxidant Capacity and Phytochemical Composition of the Comorian Tea}

The phytochemical composition (polyphenolic compounds, monoterpenes, vitamin $\mathrm{C}$, organic acids, and carotenoids), total polyphenolic content (TPC), and the antioxidant capacity (AOC) of the Comorian tea were defined by spectrophotometric and chromatographic analysis. The results were reported in Table 1.

Table 1. Total phenolics (TPC), antioxidant capacity (AOC) and phytochemical composition of the Comorian tea.

\begin{tabular}{|c|c|c|c|c|}
\hline & & \multicolumn{3}{|c|}{ Comorian Tea } \\
\hline & & Mean Value & $S D$ & Units \\
\hline Total polyphenolic content & $\mathrm{TPC}$ & 4511.50 & 74.41 & $\mathrm{mg}_{\mathrm{GAE}} / 100 \mathrm{~g} \mathrm{DW}$ \\
\hline \multirow[t]{2}{*}{ Antioxidant capacity } & AOC & 578.65 & 6.48 & $\mathrm{mmol} \mathrm{Fe} \mathrm{L}^{2+} / \mathrm{Kg} \mathrm{DW}$ \\
\hline & caffeic acid & 2.16 & 0.43 & \\
\hline \multirow{5}{*}{ Cinnamic acids } & chlorogenic acid & 151.94 & 2.33 & \multirow{5}{*}{$\mathrm{mg} / 100 \mathrm{~g} \mathrm{DW}$} \\
\hline & coumaric acid & 102.02 & 12.82 & \\
\hline & ferulic acid & 48.47 & 6.29 & \\
\hline & hyperoside & 44.67 & 4.15 & \\
\hline & isoquercitrin & n.d. & / & \\
\hline \multirow[t]{3}{*}{ Flavonols } & quercetin & 199.64 & 6.49 & \multirow[t]{3}{*}{$\mathrm{mg} / 100 \mathrm{~g} \mathrm{DW}$} \\
\hline & quercitrin & n.d. & / & \\
\hline & rutin & 75.52 & 3.54 & \\
\hline \multirow{2}{*}{ Benzoic acids } & ellagic acid & 125.70 & 5.27 & \multirow{2}{*}{$\mathrm{mg} / 100 \mathrm{~g} \mathrm{DW}$} \\
\hline & gallic acid & n.d. & / & \\
\hline \multirow{4}{*}{ Catechins } & catechin & n.d. & / & \multirow{2}{*}{$\mathrm{mg} / 100 \mathrm{~g} \mathrm{DW}$} \\
\hline & epicatechin & 21.25 & 0.34 & \\
\hline & limonene & n.d. & / & \multirow{6}{*}{$\mathrm{mg} / 100 \mathrm{~g} \mathrm{DW}$} \\
\hline & phellandrene & 12.45 & 0.34 & \\
\hline \multirow[t]{4}{*}{ Monoterpenes } & sabinene & 5.14 & 0.94 & \\
\hline & $\gamma$-terpinene & 83.96 & 5.26 & \\
\hline & terpinolene & 9.96 & 0.66 & \\
\hline & citric acid & 94.63 & 1.35 & \\
\hline \multirow{5}{*}{ Organic acids } & malic acid & 7.34 & 0.20 & \multirow{5}{*}{$\mathrm{mg} / 100 \mathrm{~g}$ DW } \\
\hline & oxalic acid & 135.66 & 1.66 & \\
\hline & quinic acid & 69.13 & 2.54 & \\
\hline & succinic acid & 633.10 & 32.27 & \\
\hline & tartaric acid & 41.53 & 1.08 & \\
\hline \multirow{2}{*}{ Vitamin C } & ascorbic acid & 19.24 & 0.15 & \multirow{2}{*}{$\mathrm{mg} / 100 \mathrm{~g} \mathrm{DW}$} \\
\hline & dehydroascorbic acid & 12.42 & 0.12 & \\
\hline \multirow{6}{*}{ Carotenoids } & $\alpha$-carotene & n.d. & / & \multirow{6}{*}{$\mu \mathrm{g} / \mathrm{g} \mathrm{DW}$} \\
\hline & $\beta$-carotene & 1.93 & 0.56 & \\
\hline & $\beta$-cryptoxanthin & 1.55 & 0.37 & \\
\hline & lutein & 0.25 & 0.08 & \\
\hline & lycopene & n.d. & / & \\
\hline & zeaxanthin & 0.23 & 0.04 & \\
\hline
\end{tabular}

$\mathrm{GAE}=$ gallic acid equivalent; $\mathrm{DW}=$ dried weight; $\mathrm{SD}=$ standard deviation.

In this research, the Folin-Ciocalteu method used for TPC evaluation showed that the Comoros tea presented a TPC of $4511.50 \pm 74.41 \mathrm{mg}_{\mathrm{GAE}} / 100 \mathrm{~g} \mathrm{DW}$, a value statistically higher $(\mathrm{F}=230.838 ; \mathrm{P}(\mathrm{F})=3.55 \mathrm{E}-13 ; p<0.05)$ than the TPCs of the different plants included in the Comorian tea. Moreover, the Ferric Reducing Antioxidant Power (FRAP) assay was used to evaluate the antioxidant capacity of the Comorian tea in comparison to the single plants used to prepare it. The Comorian tea showed an AOC of $578.65 \pm 6.48 \mathrm{mmol}$ $\mathrm{Fe}^{2+} / \mathrm{Kg}$ DW, a value statistically higher $(\mathrm{F}=3227.498 ; \mathrm{P}(\mathrm{F})=1.35 \mathrm{E}-21 ; p<0.05)$ if compared to all the AOC values obtained in the single plants (Table 2). 
Table 2. Total phenolics (TPC) and antioxidant capacity (AOC) of the analysed plant species that constitute the Comorian tea.

\begin{tabular}{|c|c|c|c|c|c|c|c|}
\hline & & \multicolumn{3}{|c|}{ Total Polyphenolic Content } & \multicolumn{3}{|c|}{ Antioxidant Capacity } \\
\hline \multirow[t]{3}{*}{ Species } & \multirow[t]{3}{*}{ ID } & \multicolumn{3}{|c|}{ TPC } & \multicolumn{3}{|c|}{ AOC } \\
\hline & & \multicolumn{2}{|c|}{$\left(\mathrm{mg}_{\mathrm{GAE}} / 100 \mathrm{~g} \mathrm{DW}\right)$} & \multicolumn{4}{|c|}{$\left(\mathrm{mmol} \mathrm{Fe}{ }^{2+} / \mathrm{Kg} \mathrm{DW}\right)$} \\
\hline & & mean value & SD & Tukey & mean value & SD & Tukey \\
\hline Aphloia theiformis & $\mathrm{C} 2$ & 3281.65 & 159.86 & c & 327.65 & 2.94 & $\mathrm{f}$ \\
\hline Cymbopogon nardus & $\mathrm{C} 4$ & 1021.88 & 47.75 & a & 197.41 & 6.55 & $\mathrm{~d}$ \\
\hline Ocimum americanum & $\mathrm{C} 5$ & 695.37 & 37.91 & a & 135.19 & 1.52 & a \\
\hline Ocimum gratissimum & C6 & 1958.94 & 370.64 & $\mathrm{~b}$ & 186.33 & 1.94 & c \\
\hline Plectranthus amboinicus & $\mathrm{C} 7$ & 950.96 & 31.01 & a & 173.20 & 3.80 & $\mathrm{~b}$ \\
\hline Cinnamomum verum & $\mathrm{C} 12$ & 3925.23 & 220.70 & $\mathrm{~d}$ & 316.62 & 4.22 & e \\
\hline
\end{tabular}

Mean value and standard deviation (SD) of each sample are given $(\mathrm{N}=3)$. Different letters for each class indicate the significant differences at $p<0.05$. Each letter represents a different statistical group. GAE = gallic acid equivalent; DW = dried weight.

The contribution of all the bioactive classes to the total phytocomplex of the Comorian tea was evaluated by grouping the selected phytochemicals into the following classes: polyphenolic compounds (as the sum of cinnamic acids, flavonols, benzoic acids and catechins), monoterpenes, organic acids, vitamin C, and carotenoids (mean values were considered) (Figure 2).

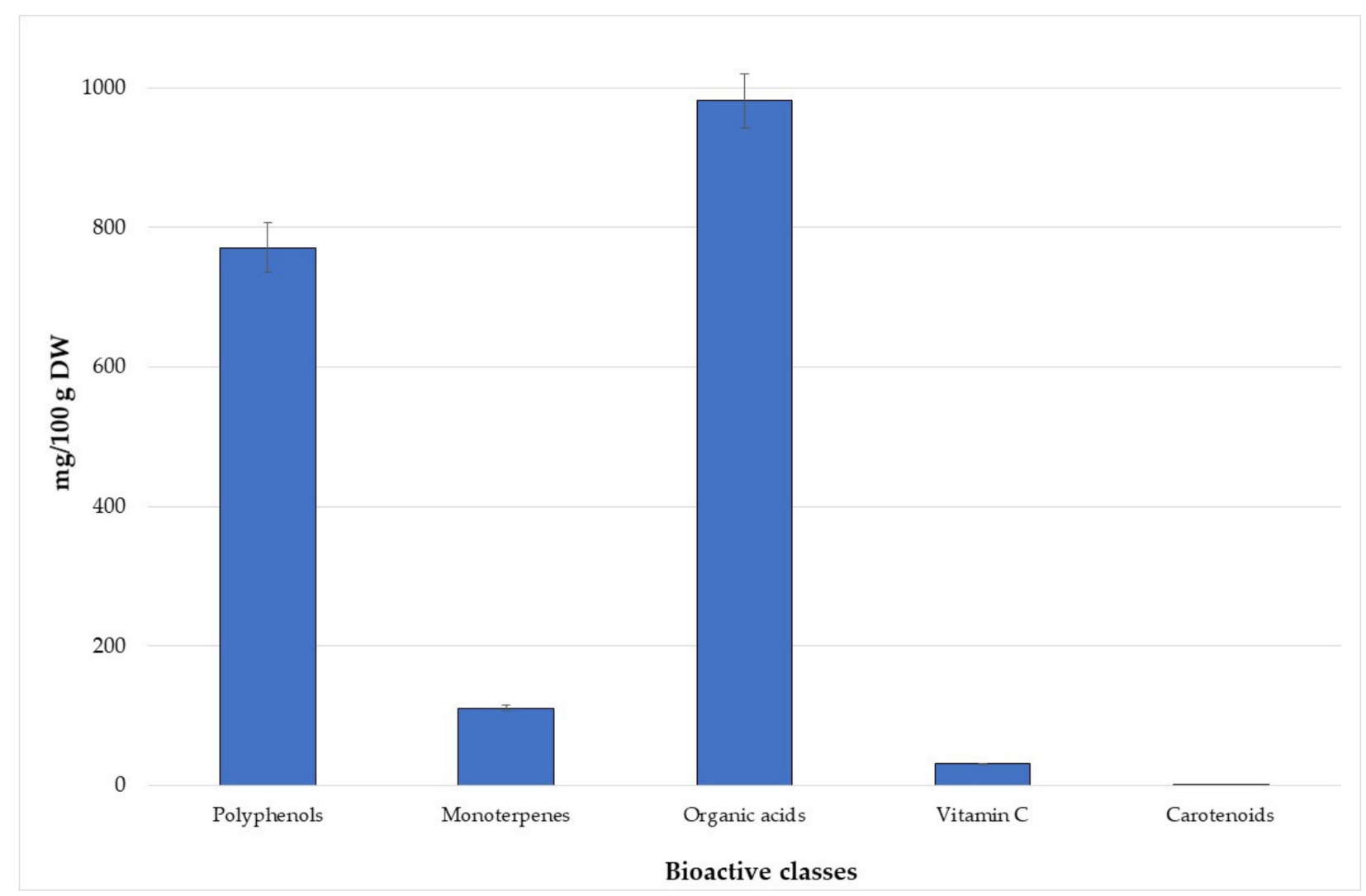

Figure 2. Amounts of all the considered bioactive classes in the Comorian tea. The mean value and standard deviations are given $(\mathrm{N}=3)$. DW = dried weight.

The polyphenolic fraction (771.37 $\pm 35.76 \mathrm{mg} / 100 \mathrm{~g} \mathrm{DW})$ and organic acids $(981.40 \pm 38.38 \mathrm{mg} / 100 \mathrm{~g} \mathrm{DW})$ were the most important phytochemical classes in the Comorian tea $(40.68 \%$ and $51.75 \%$ of the total phytocomplex, respectively), followed by the monoterpenes $(5.88 \%)$ and vitamin C $(1.67 \%)$, while carotenoids were detected in trace $(0.02 \%)$. These results confirmed that the synergistic use of a mix of different species 
to prepare a tea or other hot drink (infusion and decoction) allow improvement of its health-promoting composition compared with a beverage obtained from a single plant, as reported in other studies $[19,29]$.

Within the polyphenolic group, flavonols and cinnamic acids were the most important classes (with mean values of $41.46 \%$ and $39.49 \%$, respectively), followed by benzoic acids (with a mean value of $16.30 \%$ ). Catechins were detected in low quantities (2.75\%). In particular, chlorogenic acid (151.94 $\pm 2.33 \mathrm{mg} / 100 \mathrm{~g}$ DW), quercetin (199.64 $\pm 6.49 \mathrm{mg} / 100 \mathrm{~g} \mathrm{DW})$, and ellagic acid $(125.70 \pm 5.27 \mathrm{mg} / 100 \mathrm{~g}$ DW) represented the most abundant phenolics in the Comorian tea.

\subsection{Total Phenolics and Antioxidant Capacity of the Individual Plants That Constitute the Comorian Tea}

The antioxidant properties and phenolic compounds are often correlated in plants because of the action of phenolics as electron donors in free radical reactions [30]. In this research, the Folin-Ciocalteu method for TPC evaluation was used to show that there are significant differences $(p<0.05)$ in the TPCs of the different plants included in the present study. The TPCs of the extracts ranged from $695.37 \pm 37.91$ (Ocimum americanum, C5) to $3925.23 \pm 220.70 \mathrm{mg}_{\mathrm{GAE}} / 100 \mathrm{~g}$ DW (Cinnamomum verum, C12), with Aphloia theiformis (C2) and Ocimum gratissimum (C6) showing intermediate values (3281.65 $\pm 159.86 \mathrm{mg}_{\mathrm{GAE}} / 100 \mathrm{~g}$ DW and $1958.94 \pm 370.64 \mathrm{mg}_{\mathrm{GAE}} / 100 \mathrm{~g}$ DW, respectively), followed by Cymbopogon nardus and Plectranthus amboinicus (Table 2). These values were similar to or higher than other similar studies confirming these plants as a good source of phenolic compounds for Comorian people [31-33].

Reactive oxygen species (ROS) present a very important role in age-related and ageing diseases. For this reason, the consumption of antioxidants as food supplements may slow the ageing process [34]. In this study, a preliminary evaluation of the antioxidant capacity of the six analysed plants was performed based on the FRAP screening assay. The mechanism involved in the FRAP assay is to measures the production of Fe(II) from Fe(III) at $595 \mathrm{~nm}$. The presence of a high antioxidant capacity results in the appearance of an intense purplish-blue colour [35]. Although the FRAP protocol is an in vitro chemical-based assay with little application in biological systems (antioxidant action includes up-regulation of detoxifying enzymes and antioxidant compounds, modulation of redox cell signaling and gene expression, and it is not limited to scavenging free radicals), many studies in the scientific literature highlighted that it may show the potential of a plant material as inhibitor of a target-molecule oxidation; this chemical-based method is useful for screening, it is low cost, high-throughput and yields an index value (expressed as ferrous iron equivalents) that allows ordering and comparing several materials to test the antioxidant power of natural products [36,37]. In any case, there are many oxidative-stress biomarkers to investigate and define the antioxidant capacity as shown by Frijhoff et al. [38]. In this study, Aphloia theiformis (C2) and Cinnamomum verum (C12) extracts were found to have the most antioxidants, with FRAP mean values of $327.65 \pm 2.94$ and $316.62 \pm 4.22 \mathrm{mmol} \mathrm{Fe} / \mathrm{Kg}$ DW, respectively, while the other plants showed lower AOC values (about 130-200 mmol $\mathrm{Fe}^{2+} / \mathrm{Kg}$ DW) in accordance with other studies $[39,40]$. The AOC mean values were compared by using Tukey's HSD post-hoc comparison test at $p<0.05$, and significant statistical differences were observed among all the plant extracts (each plant constituted a statistically independent group). Moreover, the antioxidant results were in a very good correlation with the TPC values $(r=0.93)$ confirming that the strong antioxidant properties of these plants are mainly due to the high phenolic amounts $[8,10]$. However, evaluating the direct correlation between total phenolics and the antioxidant capacity together with the contribution of all other antioxidant compounds may be very difficult due to the additive and synergistic interaction and combination among the several health-promoting substances (phytocomplex). Indeed, each antioxidant molecule could improve the potential of the others, and this action may influence the total response [41]. This additive effect may explain the statistically significant differences among the antioxidant capacities of the different analysed plants; therefore, plants with the highest values of vitamin $C$ and total 
phenolics did not always present the highest values of antioxidant capacity. Moreover, the antioxidant capacity of the mixture of these plants (the Comorian tea) showed a very strong correlation with cinnamic acids $(r=0.98)$, flavonols $(r=0.99)$, benzoic acids $(r=0.94)$, catechins $(r=0.98)$, organic acids $(r=0.92)$, and vitamin $C(r=0.99)$.

\subsection{Phytochemical Composition of the Individual Plants That Constitute the Comorian Tea}

The phytochemical composition (polyphenolic compounds, monoterpenes, vitamin C, organic acids, and carotenoids) of the six plant species, the main constituents of Comorian tea, was defined by HPLC-DAD analysis based on 32 biomarkers. The contribution of all the bioactive classes to the total phytocomplex for each plant was evaluated by grouping the selected phytochemicals into the following classes: polyphenolic compounds (as the sum of cinnamic acids, flavonols, benzoic acids and catechins), monoterpenes, organic acids, vitamin C, and carotenoids (mean values were considered) (Figure 3).

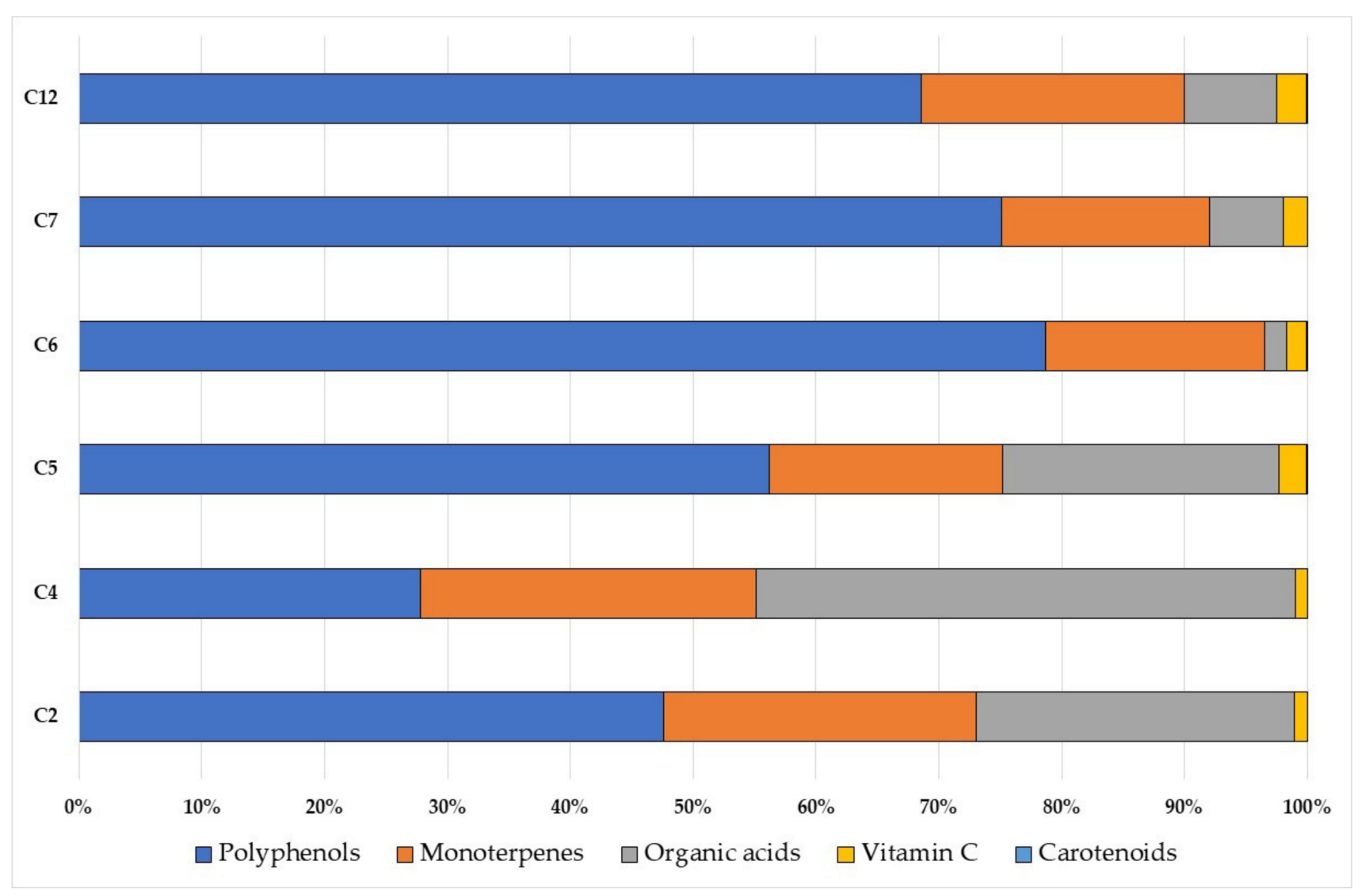

Figure 3. Evaluation of the contribution of each bioactive class to the total phytocomplex for each used plant based on the selected phytochemical classes. The mean value of each analysed sample is given $(\mathrm{N}=3)$. The colours identify the different phytochemical classes: Aphloia theiformis (Vahl) Benn.-C2, Cinnamomum verum J. Presl-C12, Ocimum gratissimum L.-C6, Plectranthus amboinicus (Lour.) Spreng.-C7, Cymbopogon nardus (L.) Rendle C4, Ocimum americanum L.-C5.

Within the polyphenolic group, flavonols and cinnamic acids were the most important classes (with mean values of $46 \%$ and $28 \%$, respectively), followed by benzoic acids (with a mean value of $21 \%)$. Catechins were detected in low quantities (0.1-12\%). In particular, C. nardus (C4), O. americanum (C5), and O. gratissimum (C6) mainly contributed to flavonols (85.8\%, 60.1\%, and 72.2\%, respectively), while A. theiformis (C2) and P. amboinicus (C7) provided a specific contribution to cinnamic acids $(46.6 \%$ and $55.42 \%$, respectively) as reported in other studies [10,12]. Benzoic acids were primarily derived from $A$. theiformis (C2) and C. verum (C12) with values of $38.0 \%$ and $52.6 \%$, respectively. The main contribution to catechins was due to $A$. theiformis (C2) with a mean value of $11.5 \%$, while the other plants 
provided a lower contribution (about $0.1-5 \%$ for each plant). These results confirmed the high health-promoting value of the plants used in the Comorian tea, in particular A. theiformis, as reported in other similar studies $[31,39,42]$. In Figure 4 the amounts of each phenolic class for all the analysed plants were reported.

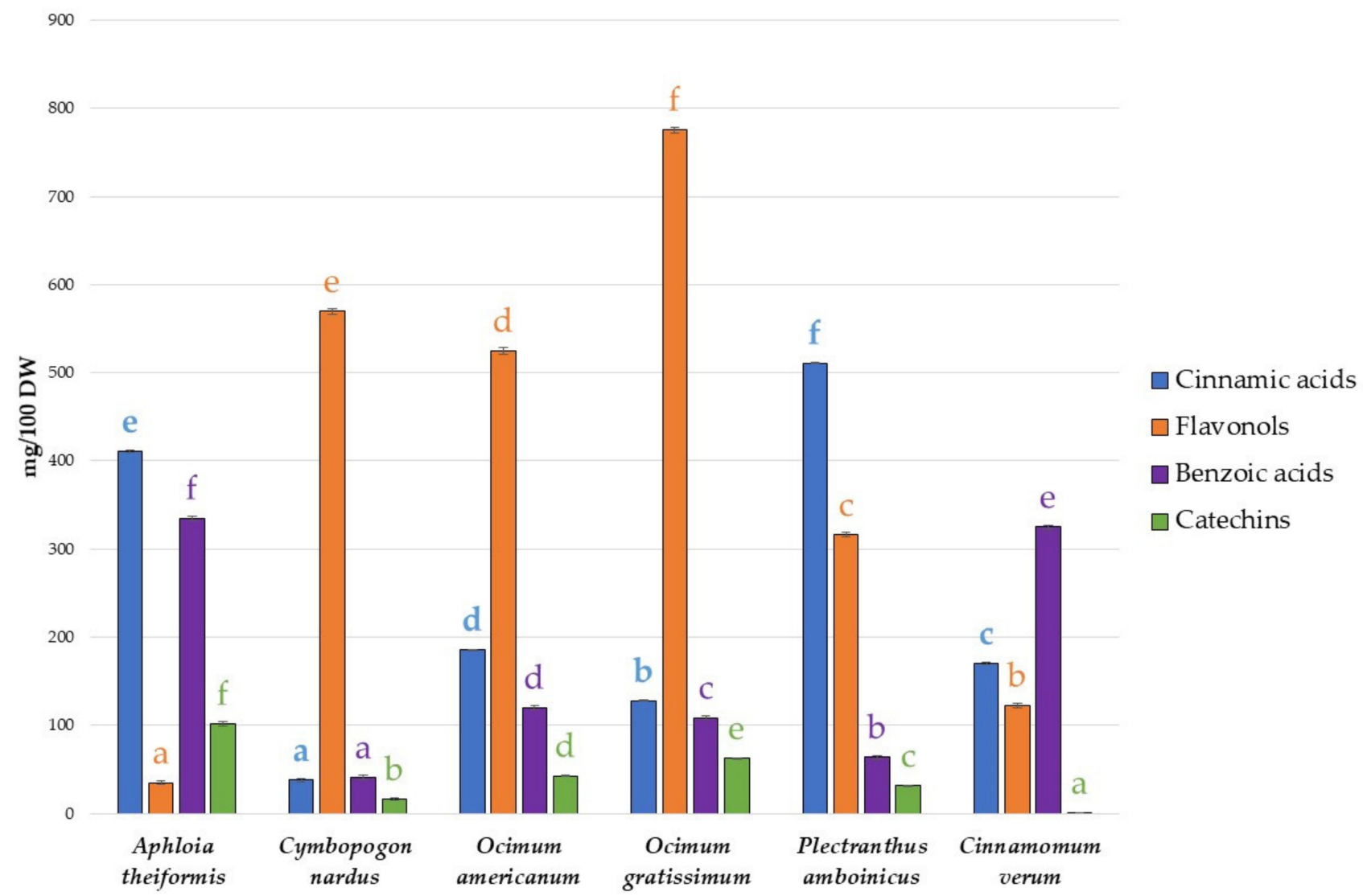

Figure 4. Phenolic composition of the individual plants that constitute the Comorian tea based on the selected phytochemical classes. The mean value of each analysed sample is given $(\mathrm{N}=3)$. Different letters for each class indicate the significant differences at $p<0.05$. The colours identify the different polyphenolic classes.

Flavonols were the main phenolics in the analysed plants, except in A. theiformis (C2), followed by phenolic acids with great variability among the species (Table 3). O. gratissimum (C6) displayed the highest flavonol levels (775.68 $\pm 3.21 \mathrm{mg} / 100 \mathrm{~g}$ DW), in particular quercetin (511.21 $\pm 0.96 \mathrm{mg} / 100 \mathrm{~g} \mathrm{DW})$ and hyperoside (121.13 $\pm 0.48 \mathrm{mg} / 100 \mathrm{~g} \mathrm{DW})$ as reported in other studies $[43,44]$. This value was higher than the average of the other species, as confirmed by Tukey's test $(p<0.05)$. Flavonols show important health-promoting properties in humans because they may inhibit in vitro oxidation of low-density lipoproteins and cyclooxygenase and modulate the metabolism of arachidonic acid. Moreover, they may attenuate inflammation and quench active oxygen species inhibit $[45,46]$.

A. theiformis (C2) showed high content of catechins (Table 4), which was represented mainly by (+)-catechin $(73.76 \pm 1.41 \mathrm{mg} / 100 \mathrm{~g} \mathrm{DW})$ and (-)-epicatechin $(27.75 \pm 0.98 \mathrm{mg} /$ $100 \mathrm{~g} \mathrm{DW})$, confirming the results reported by similar studies [29,39]. In the other plants, catechins were mainly characterised by epicatechin (about 15-60 mg/100 g DW), except for C. verum (C12) that only showed catechin in trace amounts ( $<1 \mathrm{mg} / 100 \mathrm{~g}$ DW). The quantification of catechins is very important because these molecules may inhibit (i) cyclooxygenase enzymes, (ii) proliferation of human cancer cell lines, and (iii) lipid peroxidation [47]. 
Table 3. Flavonols in the analysed plant material.

\begin{tabular}{|c|c|c|c|c|c|c|c|c|c|c|c|}
\hline \multirow{4}{*}{ Species } & \multirow{4}{*}{ ID } & \multicolumn{10}{|c|}{ Flavonols } \\
\hline & & \multicolumn{2}{|c|}{ Hyperoside } & \multicolumn{2}{|c|}{ Isoquercitrin } & \multicolumn{2}{|c|}{ Quercetin } & \multicolumn{2}{|c|}{ Quercitrin } & \multicolumn{2}{|c|}{ Rutin } \\
\hline & & \multicolumn{2}{|c|}{$(\mathrm{mg} / 100 \mathrm{~g} \mathrm{DW})$} & \multicolumn{2}{|c|}{$(\mathrm{mg} / 100 \mathrm{~g} \mathrm{DW})$} & \multicolumn{2}{|c|}{$(\mathrm{mg} / 100 \mathrm{~g} \mathrm{DW})$} & \multicolumn{2}{|c|}{$(\mathrm{mg} / 100 \mathrm{~g} \mathrm{DW})$} & \multicolumn{2}{|c|}{$(\mathrm{mg} / 100 \mathrm{~g} \mathrm{DW})$} \\
\hline & & $\begin{array}{l}\text { mean } \\
\text { value }\end{array}$ & SD & $\begin{array}{l}\text { mean } \\
\text { value }\end{array}$ & SD & $\begin{array}{l}\text { mean } \\
\text { value }\end{array}$ & SD & $\begin{array}{l}\text { mean } \\
\text { value }\end{array}$ & SD & $\begin{array}{l}\text { mean } \\
\text { value }\end{array}$ & SD \\
\hline Aphloia theiformis & $\mathrm{C} 2$ & n.d. & / & 8.30 & 0.51 & n.d. & / & 26.56 & 1.49 & n.d. & / \\
\hline Cymbopogon nardus & $\mathrm{C} 4$ & 151.33 & 0.63 & 53.38 & 0.47 & n.d. & / & 184.16 & 1.48 & 180.83 & 0.68 \\
\hline Ocimum americanum & C5 & 192.46 & 0.61 & n.d. & / & 248.82 & 1.39 & 75.82 & 1.47 & 7.71 & 0.58 \\
\hline Ocimum gratissimum & C6 & 121.13 & 0.48 & 70.36 & 0.39 & 511.21 & 0.96 & 72.98 & 1.43 & n.d. & / \\
\hline Plectranthus amboinicus & $\mathrm{C} 7$ & n.d. & / & n.d. & / & 225.69 & 1.23 & 90.26 & 1.44 & n.d. & / \\
\hline Cinnamomum verum & $\mathrm{C} 12$ & n.d. & / & 2.21 & 0.49 & 102.95 & 1.29 & 6.73 & 1.57 & 10.38 & 0.68 \\
\hline
\end{tabular}

Mean value and standard deviation $(\mathrm{SD})$ of each sample are given $(\mathrm{N}=3)$. Results are expressed as $\mathrm{mg} / 100 \mathrm{~g} \mathrm{DW}$. DW = dried weight. n.d. $=$ not detected.

Table 4. Levels of catechins in the analysed species.

\begin{tabular}{cccccc}
\hline \multicolumn{1}{c}{ Species } & \multicolumn{4}{c}{ Catechins } \\
\hline & ID & \multicolumn{2}{c}{ (+)-Catechin } & \multicolumn{2}{c}{ (-)-Epicatechin } \\
\hline & & \multicolumn{2}{c}{$(\mathrm{mg} / 100 \mathrm{~g}$ DW $)$} & \multicolumn{2}{c}{$(\mathrm{mg} / 100 \mathrm{~g}$ DW $)$} \\
\cline { 3 - 6 } & & mean value & SD & mean value & SD \\
\hline Aphloia theiformis & $\mathrm{C} 2$ & 73.76 & 1.41 & 27.75 & 0.98 \\
Cymbopogon nardus & $\mathrm{C} 4$ & n.d. & $/$ & 15.97 & 0.98 \\
Ocimum americanum & $\mathrm{C} 5$ & n.d. & $/$ & 42.51 & 0.98 \\
Ocimum gratissimum & $\mathrm{C} 6$ & n.d. & $/$ & 62.56 & 0.85 \\
Plectranthus amboinicus & $\mathrm{C} 7$ & n.d. & $/$ & 31.30 & 0.94 \\
Cinnamomum verum & C12 & 0.70 & 0.16 & n.d. & $/$ \\
\hline
\end{tabular}

Mean value and standard deviation (SD) of each sample are given $(\mathrm{N}=3)$. Results are expressed as $\mathrm{mg} / 100 \mathrm{~g} \mathrm{DW}$. $\mathrm{DW}=$ dried weight. n.d. $=$ not detected.

Chlorogenic, coumaric and ferulic acids were quantified in almost all the plants, in particular in A. theiformis (C2) and P. amboinicus (C7), as shown in Table 5. Caffeic acid was only detected in Aphloia theiformis (C2), C. nardus (C4), and C. verum (C12) (2-8 mg/100 g DW). Cinnamic acids (such as caffeic acid) can inhibit or reduce thrombotic tendency, as reported in several studies $[46,48]$.

Table 5. Levels of catechins in the analysed species.

\begin{tabular}{|c|c|c|c|c|c|c|c|c|c|}
\hline \multirow[b]{2}{*}{ Species } & \multirow[b]{2}{*}{ ID } & \multicolumn{8}{|c|}{ Cinnamic acids } \\
\hline & & \multicolumn{2}{|c|}{ Caffeic Acid } & \multicolumn{2}{|c|}{ Chlorogenic Acid } & \multicolumn{2}{|c|}{ Coumaric Acid } & \multicolumn{2}{|c|}{ Ferulic Acid } \\
\hline & & \multicolumn{2}{|c|}{$(\mathrm{mg} / 100 \mathrm{~g} \mathrm{DW})$} & \multicolumn{2}{|c|}{$(\mathrm{mg} / 100 \mathrm{~g} \mathrm{DW})$} & \multicolumn{2}{|c|}{$(\mathrm{mg} / 100 \mathrm{~g} \mathrm{DW})$} & \multicolumn{2}{|c|}{$(\mathrm{mg} / 100 \mathrm{~g} \mathrm{DW})$} \\
\hline & & $\begin{array}{l}\text { mean } \\
\text { value }\end{array}$ & SD & $\begin{array}{l}\text { mean } \\
\text { value }\end{array}$ & SD & $\begin{array}{l}\text { mean } \\
\text { value }\end{array}$ & SD & $\begin{array}{l}\text { mean } \\
\text { value }\end{array}$ & SD \\
\hline Aphloia theiformis & $\mathrm{C} 2$ & 2.61 & 0.06 & 96.94 & 0.31 & 46.17 & 0.47 & 265.19 & 1.35 \\
\hline Cymbopogon nardus & $\mathrm{C} 4$ & 3.99 & 0.07 & n.d. & / & 2.15 & 0.43 & 31.52 & 1.37 \\
\hline Ocimum americanum & C5 & n.d. & / & 135.07 & 0.28 & 50.48 & 0.47 & n.d. & / \\
\hline Ocimum gratissimum & C6 & n.d. & / & 114.40 & 0.29 & 13.12 & 0.40 & n.d. & / \\
\hline Plectranthus amboinicus & $\mathrm{C} 7$ & n.d. & / & 131.43 & 0.26 & 53.55 & 0.47 & 325.72 & 1.33 \\
\hline Cinnamomum verum & $\mathrm{C} 12$ & 7.46 & 0.07 & 119.18 & 0.30 & 43.70 & 0.49 & n.d. & / \\
\hline
\end{tabular}

Mean value and standard deviation $(\mathrm{SD})$ of each sample are given $(\mathrm{N}=3)$. Results are expressed as $\mathrm{mg} / 100 \mathrm{~g}$ DW. DW = dried weight. n.d. $=$ not detected.

Ellagic acid was the most abundant molecule in the class of benzoic acids (Table 6), in particular in A. theiformis (C2) and C. verum (C12) with mean values of $324.60 \pm 2.32 \mathrm{mg}$ / $100 \mathrm{~g}$ DW and $325.01 \pm 2.27 \mathrm{mg} / 100 \mathrm{~g}$ DW, respectively, while gallic acid showed lower 
amounts $(<10 \mathrm{mg} / 100 \mathrm{~g}$ DW). Benzoic acids are very important molecules for human well-being due to their many health-promoting properties, such as anti-inflammatory, anticancer, anti-HIV replication, antihepatotoxic and anti-atherosclerotic capacities [49]. These results are useful to confirm the traditional use of these plants because they showed a complementary composition that may potentially contribute to the health-promoting synergistic and additive effects on Comorian people.

Table 6. Amounts of benzoic acids in the analysed plants.

\begin{tabular}{cccccc}
\hline & \multicolumn{4}{c}{ Benzoic acids } \\
\hline Species & ID & \multicolumn{2}{c}{ Ellagic Acid } & \multicolumn{2}{c}{ Gallic Acid } \\
\hline & & \multicolumn{2}{c}{$(\mathrm{mg} / 100 \mathrm{~g}$ DW $)$} & \multicolumn{2}{c}{$(\mathrm{mg} / 100 \mathrm{~g}$ DW $)$} \\
\cline { 3 - 6 } & & mean value & SD & mean value & SD \\
\hline Aphloia theiformis & $\mathrm{C} 2$ & 324.60 & 2.32 & 10.14 & 0.28 \\
Cymbopogon nardus & $\mathrm{C} 4$ & 39.35 & 2.32 & 1.50 & 0.28 \\
Ocimum americanum & $\mathrm{C} 5$ & 119.84 & 2.33 & n.d. & $/$ \\
Ocimum gratissimum & $\mathrm{C} 6$ & 108.55 & 2.01 & n.d. & $/$ \\
Plectranthus amboinicus & $\mathrm{C} 7$ & 63.50 & 2.25 & n.d. & $/$ \\
Cinnamomum verum & $\mathrm{C} 12$ & 325.01 & 2.27 & n.d. & $/$ \\
\hline
\end{tabular}

Mean value and standard deviation (SD) of each sample are given $(\mathrm{N}=3)$. Results are expressed as $\mathrm{mg} / 100 \mathrm{~g} \mathrm{DW}$. $\mathrm{DW}=$ dried weight. n.d. $=$ not detected.

The analysed species also presented a good content of monoterpenes (Table 7) and vitamin C (Table 8). Monoterpenes are bioactive substances used extensively for their aromatic properties combined with their anti-inflammatory and antioxidant activities [50]. Most of these compounds also shows antitumor and antibacterial capacity [51]. A. theiformis (C2) and C. nardus (C4) showed high contents of monoterpenes (400-700 mg/100 g DW). Limonene was the predominant compound and reached quantities of $635.61 \pm 16.02 \mathrm{mg} /$ $100 \mathrm{~g}$ DW in C. nardus (C4). High limonene amounts were also found in the O. americanum (C5) and P. amboinicus (C7) (about $200 \mathrm{mg} / 100 \mathrm{~g} \mathrm{DW}$ ). $\gamma$-terpinene was detected in high quantities, in particular in A. theiformis (C2) $(261.02 \pm 3.98 \mathrm{mg} / 100 \mathrm{~g} \mathrm{DW})$ and C. verum (C12) $(181.28 \pm 2.30 \mathrm{mg} / 100 \mathrm{~g} \mathrm{DW})$, similar to other studies [32,42]. The literature reported a chemopreventive action of monoterpenes against rodent mammary, lung, forestomach skin and liver cancers [52]. Phellandrene, sabinene and terpinolene were also quantified but at lower contents $(<15 \mathrm{mg} / 100 \mathrm{~g} \mathrm{DW})$.

Table 7. Monoterpenes in analysed plant material.

\begin{tabular}{|c|c|c|c|c|c|c|c|c|c|c|c|}
\hline \multirow{4}{*}{ Species } & \multirow{4}{*}{ ID } & \multicolumn{10}{|c|}{ Monoterpenes } \\
\hline & & \multicolumn{2}{|c|}{ Limonene } & \multicolumn{2}{|c|}{ Phellandrene } & \multicolumn{2}{|c|}{ Sabinene } & \multicolumn{2}{|c|}{$\gamma$-Terpinene } & \multicolumn{2}{|c|}{ Terpinolene } \\
\hline & & \multicolumn{2}{|c|}{ (mg/100 g DW) } & \multicolumn{2}{|c|}{$(\mathrm{mg} / 100 \mathrm{~g}$ DW) } & \multicolumn{2}{|c|}{$(\mathrm{mg} / 100 \mathrm{~g} \mathrm{DW})$} & \multicolumn{2}{|c|}{$(\mathrm{mg} / 100 \mathrm{~g} \mathrm{DW})$} & \multicolumn{2}{|c|}{$(\mathrm{mg} / 100 \mathrm{~g} \mathrm{DW})$} \\
\hline & & $\begin{array}{l}\text { mean } \\
\text { value }\end{array}$ & SD & $\begin{array}{l}\text { mean } \\
\text { value }\end{array}$ & SD & $\begin{array}{l}\text { mean } \\
\text { value }\end{array}$ & SD & $\begin{array}{l}\text { mean } \\
\text { value }\end{array}$ & SD & $\begin{array}{l}\text { mean } \\
\text { value }\end{array}$ & SD \\
\hline Aphloia theiformis & $\mathrm{C} 2$ & 196.42 & 14.37 & 13.78 & 0.36 & n.d. & / & 261.02 & 3.98 & n.d. & / \\
\hline Cymbopogon nardus & $\mathrm{C} 4$ & 635.61 & 16.02 & n.d. & / & 11.78 & 0.14 & n.d. & / & 4.93 & 0.14 \\
\hline Ocimum americanum & C5 & 192.73 & 19.82 & 14.23 & 0.32 & n.d. & / & 87.65 & 4.09 & n.d. & / \\
\hline Ocimum gratissimum & C6 & 160.59 & 10.06 & 12.40 & 0.30 & n.d. & / & 70.42 & 2.54 & n.d. & / \\
\hline Plectranthus amboinicus & $\mathrm{C} 7$ & 194.16 & 6.19 & n.d. & / & 6.87 & 0.17 & n.d. & / & 6.62 & 0.09 \\
\hline Cinnamomum verum & $\mathrm{C} 12$ & n.d. & / & 7.77 & 0.44 & n.d. & / & 181.28 & 2.30 & 3.60 & 0.05 \\
\hline
\end{tabular}

Mean value and standard deviation $(\mathrm{SD})$ of each sample are given $(\mathrm{N}=3)$. Results are expressed as $\mathrm{mg} / 100 \mathrm{~g}$ DW. DW = dried weight. n.d. $=$ not detected . 
Table 8. Vitamin C in the Comorian tea.

\begin{tabular}{cccccc}
\hline & \multicolumn{5}{c}{ Vitamin C } \\
\hline Species & ID & \multicolumn{2}{c}{ Ascorbic Acid } & \multicolumn{2}{c}{ Dehydroascorbic Acid } \\
\hline & & \multicolumn{2}{c}{$(\mathrm{mg} / 100 \mathrm{~g}$ DW $)$} & \multicolumn{2}{c}{$(\mathrm{mg} / 100 \mathrm{~g}$ DW $)$} \\
\cline { 3 - 6 } & & mean value & SD & mean value & SD \\
\hline Aphloia theiformis & $\mathrm{C} 2$ & 16.19 & 0.59 & 2.68 & 0.39 \\
Cymbopogon nardus & $\mathrm{C} 4$ & 17.60 & 0.28 & 4.78 & 1.73 \\
Ocimum americanum & $\mathrm{C} 5$ & 18.79 & 1.41 & 16.48 & 0.94 \\
Ocimum gratissimum & $\mathrm{C} 6$ & 12.12 & 0.10 & 9.59 & 1.45 \\
Plectranthus amboinicus & $\mathrm{C} 7$ & 15.71 & 0.34 & 8.25 & 0.88 \\
Cinnamomum verum & $\mathrm{C} 12$ & 16.73 & 0.20 & 5.06 & 2.53 \\
\hline
\end{tabular}

Mean value and standard deviation (SD) of each sample are given $(\mathrm{N}=3)$. Results are expressed as $\mathrm{mg} / 100 \mathrm{~g} \mathrm{DW}$ DW $=$ dried weight. n.d. $=$ not detected.

For vitamin C quantification (Table 8) ascorbic and dehydroascorbic acids were considered due to their health-promoting activity in human beings, as reported in other studies [41,53]. The maximum vitamin C value was detected in O. americanum (C5) (about $35 \mathrm{mg} / 100 \mathrm{~g} \mathrm{DW}$ ), followed by P. amboinicus (C7), while the minimum content was quantified in A. theiformis (C2) (about $19 \mathrm{mg} / 100 \mathrm{~g}$ DW). These results were comparable to the values reported in Light (2004) [14] and confirmed that these plants may be a good source for vitamin $C$ uptake even if the tea preparation method could reduce these amounts before ingestion by local people.

Large differences $(p<0.05)$ in organic acid content values (Table 9) were detected among the analysed species. High levels of organic acids were observed in $C$. nardus (C4) (about $1050 \mathrm{mg} / 100 \mathrm{~g} \mathrm{DW}$ ), while O. gratissimum (C6) showed the lowest values ( $<30 \mathrm{mg} 100 \mathrm{~g} \mathrm{DW}$ ). Citric acid showed the highest values in A. theiformis (C2) and C. nardus (C4) $(231.44 \pm 2.43 \mathrm{mg} / 100 \mathrm{~g}$ DW and $164.16 \pm 2.44 \mathrm{mg} / 100 \mathrm{~g} \mathrm{DW}$, respectively), while succinic acid was the most abundant organic acid in C. nardus (C4) and O. americanum (C5) $(847.02 \pm 2.79 \mathrm{mg} / 100 \mathrm{~g}$ DW and $337.86 \pm 2.81 \mathrm{mg} / 100 \mathrm{~g} \mathrm{DW}$, respectively), as reported by similar studies $[10,17]$. Oxalic and quinic acids were only identified in A. theiformis (C2) with values of $131.06 \pm 1.83 \mathrm{mg} / 100 \mathrm{~g}$ DW and $21.00 \pm 3.19 \mathrm{mg} / 100 \mathrm{~g}$ DW, respectively, while tartaric acid was detected in all the plants $(8-65 \mathrm{mg} / 100 \mathrm{~g}$ DW), except $O$. americanum (C5). Malic acid was only detected in A. theiformis (C2) and P. amboinicus (C7) in low amounts $(<30 \mathrm{mg} / 100 \mathrm{~g} \mathrm{DW})$. These results were similar to previous studies [12,14,54], but some differences were observed probably due to the intrinsic characteristics of the considered species and the effect of (i) sample storage, (ii) extraction technique and (iii) drying treatment applied during the sample preparation $[17,55,56]$. Previous studies showed that organic acids may possess biological activity in enhancing the bioavailability of phenolics [57] and they may interfere in the reduction of reactive oxygen species (ROS) [58]. Moreover, an interaction was demonstrated between the main organic acids and ascorbic acid; in particular, these compounds, even if not directly involved in the free-radical scavenging action, could influence the antioxidant capacity of vitamin C [59]. These results (high amounts of antioxidant compounds, such as phenolics and vitamin C, together with adequate levels of organic acids and other molecules with antiradical properties) support the traditional use of these plants as a source of antioxidants for the local population in the Comoros Islands.

Six carotenoids have been considered in the analysed plants (Table 10). $\alpha$-carotene, $\beta$-carotene and $\beta$-cryptoxanthin act as provitamin $\mathrm{A}$ in the human organism, while lutein, lycopene and zeaxanthin are not characterised by a provitamin A activity [24]. $\beta$-carotene was the most important carotenoid in Ocimum spp. $(2.68 \pm 0.29 \mu \mathrm{g} / \mathrm{g}$ DW for C5 and $1.29 \pm 0.06 \mu \mathrm{g} / \mathrm{g}$ DW for C6), together with C. verum (C12) with about $2 \mu \mathrm{g} / \mathrm{g}$ DW. A. theiformis (C2) and P. amboinicus (C7) showed lower levels $(<1 \mu \mathrm{g} / \mathrm{g}$ DW). Ocimum spp. (C5 and C6) also showed high contents of $\beta$-cryptoxanthin ( $>2 \mu \mathrm{g} / \mathrm{g}$ DW), lutein (1-2 $\mu \mathrm{g} / \mathrm{g} D W)$, and zeaxanthin (1-2 $\mu \mathrm{g} / \mathrm{g} D W)$, confirming the results reported in the 
literature [60,61]. $\alpha$-carotene (from 0.3 to $0.7 \mu \mathrm{g} / \mathrm{g}$ DW) and lycopene (from 0.3 to $0.4 \mu \mathrm{g} / \mathrm{g}$ DW) were only detected in P. amboinicus (C7) and C. verum (C12). Lycopene is an antioxidant carotenoid, but it does not show vitamin A activity. Antioxidant properties of lycopene are often involved in the cellular protection system from reactive nitrogen (RNS) and reactive oxygen (ROS) species, reducing cardiovascular diseases risk (CVD) in the human organism [62].

Table 9. Levels of organic acids in the analysed species.

\begin{tabular}{|c|c|c|c|c|c|c|c|c|c|c|c|c|c|}
\hline \multirow{4}{*}{ Species } & \multirow{4}{*}{ ID } & \multicolumn{12}{|c|}{ Organic Acids } \\
\hline & & \multicolumn{2}{|c|}{ Citric Acid } & \multicolumn{2}{|c|}{ Malic Acid } & \multicolumn{2}{|c|}{ Oxalic Acid } & \multicolumn{2}{|c|}{ Quinic Acid } & \multicolumn{2}{|c|}{ Succinic Acid } & \multicolumn{2}{|c|}{ Tartaric Acid } \\
\hline & & \multicolumn{2}{|c|}{$(\mathrm{mg} / 100 \mathrm{~g} \mathrm{DW})$} & \multicolumn{2}{|c|}{$(\mathrm{mg} / 100 \mathrm{~g} \mathrm{DW})$} & \multicolumn{2}{|c|}{$(\mathrm{mg} / 100 \mathrm{~g} \mathrm{DW})$} & \multicolumn{2}{|c|}{$(\mathrm{mg} / 100 \mathrm{~g}$ DW $)$} & \multicolumn{2}{|c|}{$(\mathrm{mg} / 100 \mathrm{~g} \mathrm{DW})$} & \multicolumn{2}{|c|}{$(\mathrm{mg} / 100 \mathrm{~g} \mathrm{DW})$} \\
\hline & & $\begin{array}{l}\text { mean } \\
\text { value }\end{array}$ & $\mathrm{SD}$ & $\begin{array}{l}\text { mean } \\
\text { value }\end{array}$ & SD & $\begin{array}{l}\text { mean } \\
\text { value }\end{array}$ & SD & $\begin{array}{l}\text { mean } \\
\text { value }\end{array}$ & SD & $\begin{array}{l}\text { mean } \\
\text { value }\end{array}$ & SD & $\begin{array}{l}\text { mean } \\
\text { value }\end{array}$ & SD \\
\hline Aphloia theiformis & $\mathrm{C} 2$ & 231.44 & 2.43 & 29.01 & 1.83 & 131.06 & 0.40 & 21.00 & 3.19 & 19.45 & 2.79 & 47.82 & 1.40 \\
\hline Cymbopogon nardus & $\mathrm{C} 4$ & 164.16 & 2.44 & n.d. & / & n.d. & / & n.d. & I & 847.02 & 2.79 & 35.99 & 1.40 \\
\hline Ocimum americanum & C5 & 11.71 & 2.44 & n.d. & / & n.d. & / & n.d. & / & 337.86 & 2.81 & n.d. & / \\
\hline Ocimum gratissimum & C6 & 17.68 & 2.11 & n.d. & / & n.d. & / & n.d. & / & n.d. & / & 7.92 & 1.21 \\
\hline $\begin{array}{c}\text { Plectranthus } \\
\text { amboinicus }\end{array}$ & $\mathrm{C} 7$ & n.d. & / & 9.24 & 1.76 & n.d. & / & n.d. & / & n.d. & / & 64.47 & 1.36 \\
\hline Cinnamomum verum & $\mathrm{C} 12$ & 50.87 & 2.38 & n.d. & / & n.d. & / & n.d. & / & n.d. & / & 17.19 & 1.37 \\
\hline
\end{tabular}

Mean value and standard deviation $(\mathrm{SD})$ of each sample are given $(\mathrm{N}=3)$. Results are expressed as $\mathrm{mg} / 100 \mathrm{~g} \mathrm{DW}$. DW $=\mathrm{dried}$ weight. n.d. $=$ not detected .

Table 10. Carotenoids in the analysed plant material.

\begin{tabular}{|c|c|c|c|c|c|c|c|c|c|c|c|c|c|}
\hline \multirow{4}{*}{ Species } & \multirow{4}{*}{ ID } & \multicolumn{12}{|c|}{ Carotenoids } \\
\hline & & \multicolumn{2}{|c|}{$\alpha$-Carotene } & \multicolumn{2}{|c|}{$\beta$-Carotene } & \multirow{2}{*}{\multicolumn{2}{|c|}{$\begin{array}{c}\beta- \\
\text { Cryptoxanthin } \\
(\mu \mathrm{g} / \mathrm{g} D W)\end{array}$}} & \multicolumn{2}{|c|}{ Lutein } & \multicolumn{2}{|c|}{ Lycopene } & \multicolumn{2}{|c|}{ Zeaxanthin } \\
\hline & & \multicolumn{2}{|c|}{$(\mu \mathrm{g} / \mathrm{g} D W)$} & \multicolumn{2}{|c|}{$(\mu \mathrm{g} / \mathrm{g} D W)$} & & & \multicolumn{2}{|c|}{$(\mu \mathrm{g} / \mathrm{g} D W))$} & \multicolumn{2}{|c|}{$(\mu \mathrm{g} / \mathrm{g} D W)$} & \multicolumn{2}{|c|}{$(\mu \mathrm{g} / \mathrm{g} D W)$} \\
\hline & & $\begin{array}{l}\text { mean } \\
\text { value }\end{array}$ & $\mathrm{SD}$ & $\begin{array}{l}\text { mean } \\
\text { value }\end{array}$ & $\mathrm{SD}$ & $\begin{array}{l}\text { mean } \\
\text { value }\end{array}$ & $\mathrm{SD}$ & $\begin{array}{l}\text { mean } \\
\text { value }\end{array}$ & $\mathrm{SD}$ & $\begin{array}{l}\text { mean } \\
\text { value }\end{array}$ & SD & $\begin{array}{l}\text { mean } \\
\text { value }\end{array}$ & SD \\
\hline Aphloia theiformis & $\mathrm{C} 2$ & n.d. & / & 0.79 & 0.16 & n.d. & / & n.d. & / & n.d. & / & n.d. & / \\
\hline Cymbopogon nardus & $\mathrm{C} 4$ & n.d. & / & 0.50 & 0.06 & 0.82 & 0.15 & n.d. & / & n.d. & / & n.d. & / \\
\hline Ocimum americanum & C5 & n.d. & / & 2.68 & 0.29 & 2.29 & 0.17 & 1.34 & 0.39 & n.d. & / & 1.72 & 0.48 \\
\hline Ocimum gratissimum & C6 & n.d. & / & 1.29 & 0.06 & 1.14 & 0.04 & 2.01 & 0.69 & n.d. & / & 1.84 & 0.58 \\
\hline Plectranthus & $\mathrm{C} 7$ & 0.67 & 0.14 & 0.76 & 0.09 & n.d. & / & n.d. & / & 0.43 & 0.09 & n.d. & / \\
\hline Cinnamomum verum & $\mathrm{C} 12$ & 0.29 & 0.08 & 1.71 & 0.20 & 0.65 & 0.12 & n.d. & / & 0.39 & 0.07 & n.d. & / \\
\hline
\end{tabular}

Mean value and standard deviation $(\mathrm{SD})$ of each sample are given $(\mathrm{N}=3)$. Results are expressed as $\mu \mathrm{g} / \mathrm{g} \mathrm{DW}$. $\mathrm{DW}=\mathrm{dried}$ weight. n.d. $=$ not detected.

Processes involved in tea preparation may lower the carotenoid content in Comorian tea, since these molecules are thermolabile compounds [19,63]. Carotenoids, mainly important in the human diet because of their vitamin A activity, also show important antioxidant capacity, immune system activity, and intercellular communication action [64,65]. Epidemiological studies presented that a diet rich in carotenoids reduces the incidence of several diseases, such as cataract formation, age-related macular degeneration, cardiovascular problems and cancer $[66,67]$. For this reason, carotenoids may increase their antioxidant potential, mainly due to the high amounts of polyphenols and vitamin C.

\subsection{Multivariate Analysis}

A PCA was performed on the chemical data (content of phytochemicals together with TPC and AOC) to characterise and distinguish the analysed plant species. PCA was only applied to the effective composition of single plants. The results of the sphericity Bartlett's test $(p<0.05)$ showed significant collinearity among variables and the KMO index attained a value of 0.76 . The PCA resulted in two PCs accounting for $61.2 \%$ of the total variance, $34.3 \%$ explained by PC1 and 26.9 by PC2. The six samples were placed in the PCs plane in relation to phytochemical composition and nutraceutical properties as shown in the score plot (Figure 5). PCA gave rise to five specific groups, according to the chemical results. In particular, all the samples were distinguished at the "species" botanical level. PCA grouped samples C5 and C6 into the same block, referred to as Ocimum spp. The PCA 
loadings plot presented an association between most of the polyphenolic compounds and organic acids and PC1, and a correlation between vitamin C and monoterpenes and PC2 (Figure 6).

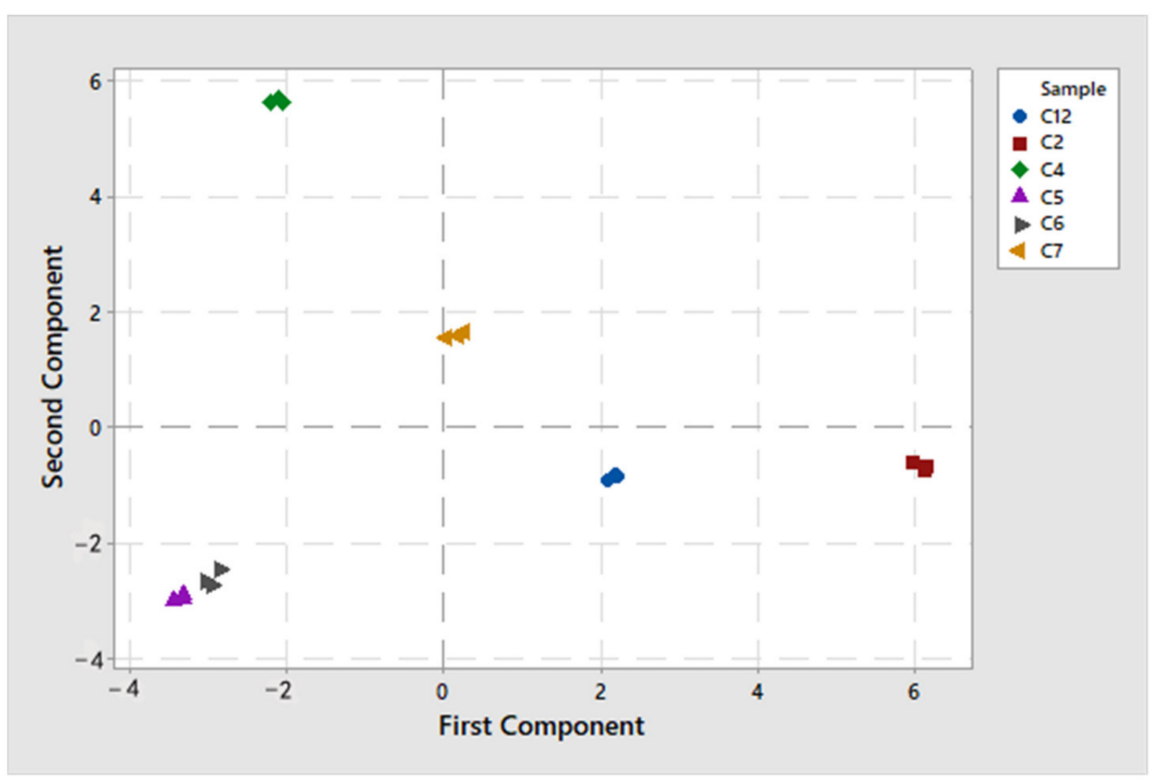

Figure 5. PCA score plot of analysed species. In this case, the selected variables included the content of all the phytochemicals, TPC, and AOC. Mean values $(\mathrm{N}=3)$ were considered for each species. Aphloia theiformis (Vahl) Benn.-C2, Cinnamomum verum J.Presl-C12, Ocimum gratissimum L.-C6, Plectranthus amboinicus (Lour.) Spreng.-C7, Cymbopogon nardus (L.) Rendle C4, Ocimum americanum L.-C5.

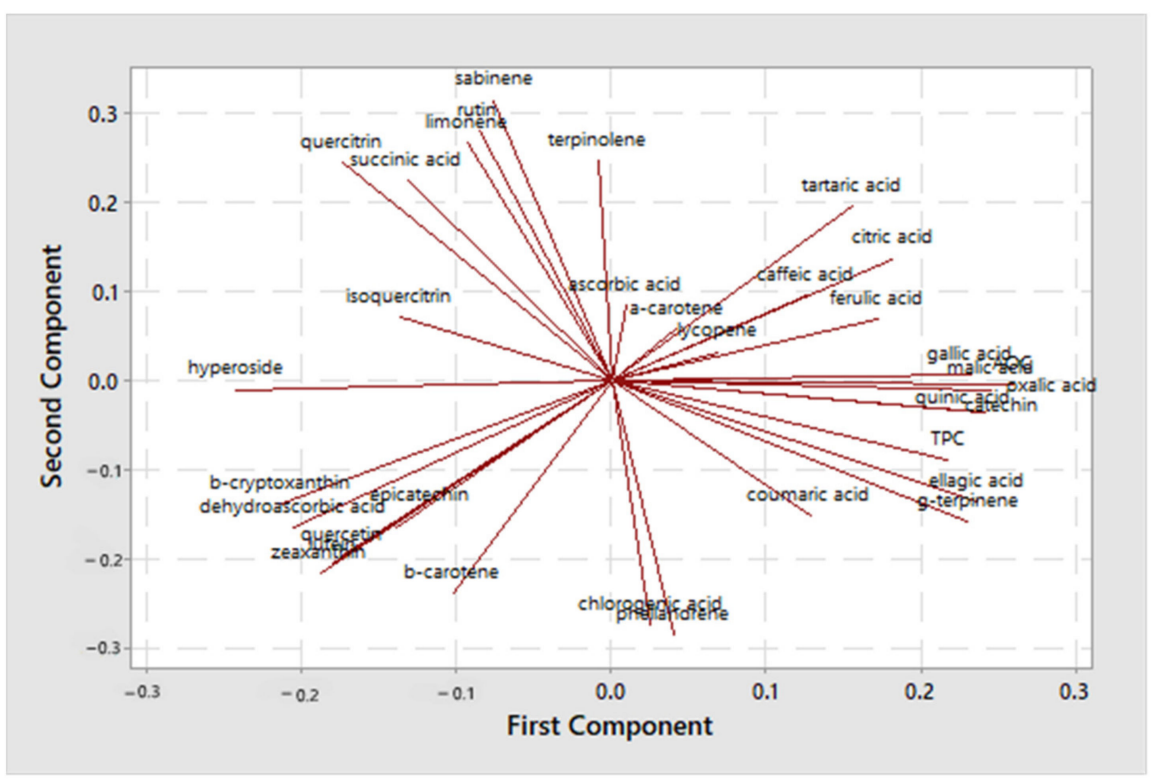

Figure 6. PCA loading plot of considered variables. In this case, the selected variables included the content of all the phytochemicals, TPC, and AOC.

More than the activity of a single compound, the health-promoting effects are the result of the additive and synergistic interactions of several bioactive compounds that jointly contribute to disease prevention [68]. For this reason, compounds belonging to the same phytochemical class were grouped in bioactive classes for the second PCA. In this case, the results of the sphericity Bartlett's test $(p<0.05)$ confirmed significant collinearity 
among variables, and the KMO index attained a value of 0.71 . The PCA resulted in two PCs accounting for $68.4 \%$ of the total variance, $43.7 \%$ explained by PC1 and 24.7 by PC2. The six samples were again placed in the PCs plane in relation to phytochemical contents and nutraceutical traits, as shown in the score plot (Figure 7). In this case, PCA gave rise to four specific groups, according to the nutraceutical results. In particular, all the samples were distinguished at the "family" botanical level. PCA grouped the samples C5, C6 and C7 into the same block, referred to as Lamiaceae. PCA loadings plot showed an association between TPC, AOC, polyphenolic compounds, carotenoids and vitamin C and PC1, and a correlation between organic acids and monoterpenes and PC2 (Figure 8). Multivariate analysis identified antioxidant compounds, such as phenolics and vitamin $\mathrm{C}$, associated with PC1, as bioactive classes with the most discriminating power among different species; these chemical classes included molecules with significant differences $(p<0.05)$ in their content among the different plants. Moreover, monoterpenes and organic acids also presented good discriminating power among samples. For this reason, all these molecules may be very important biomarkers to distinguish these plants, but further studies are necessary to confirm this hypothesis.

The results presented that classification by PCA characterised the samples in accordance with the different chemical traits and provided information on the bioactive classes and single markers that most influence the phytocomplex. This preliminary research was based on leaves of wild plants harvested in the same areas, but further studies may be carried out to investigate the influence of single plant variability and agri-environmental conditions on the considered complex matrices and evaluate potential differences in phytochemical composition. In this study, a chemometric method was applied together with the HPLC profiling technique for better recognition of the analysed extracts. Different markers were identified as the variables most important for the discrimination of different plant species, which may be applied to accurate composition control of a mixed preparation derived from several plants. For this reason, HPLC profile coupled to chemometrics could be considered as a tool of traceability to distinguish different species by their phytochemical contents and nutraceutical properties, as reported in other studies $[69,70]$.

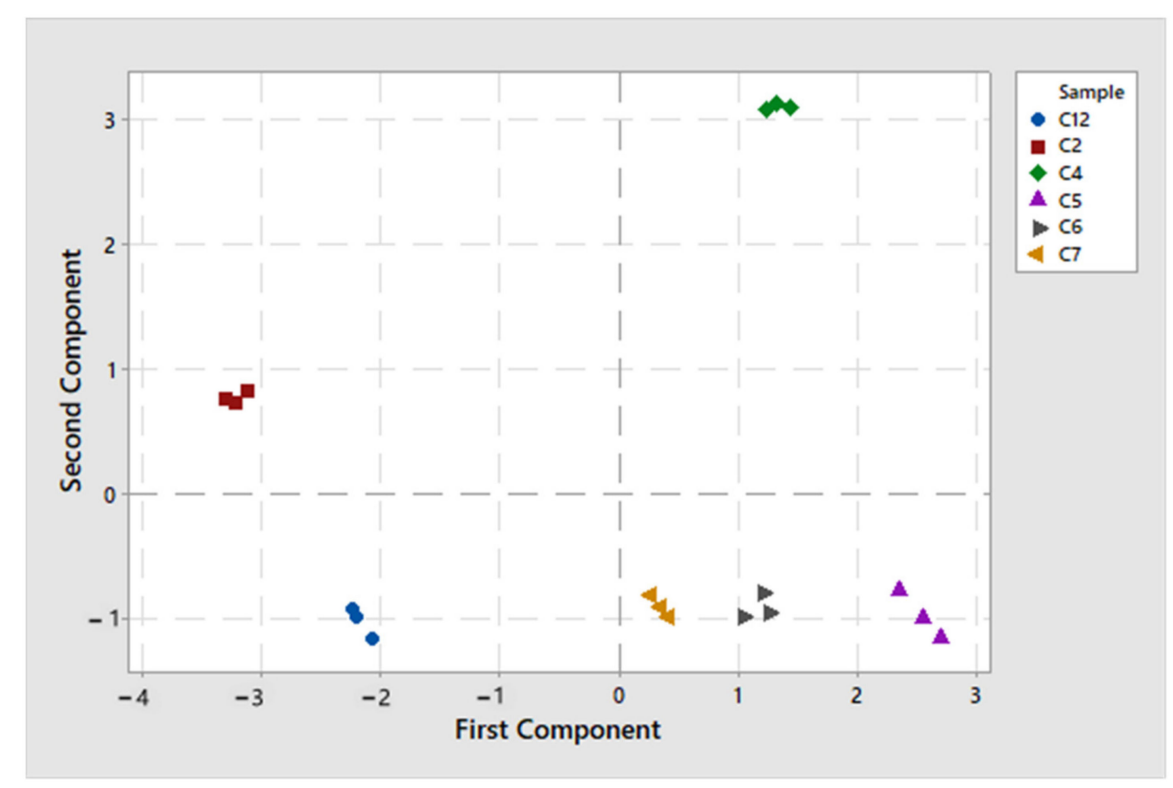

Figure 7. PCA score plot of analysed plants included in the Comorian tea. In this case, the selected variables included the content of all the bioactive classes, TPC, and AOC. Mean values $(\mathrm{N}=3)$ were considered for each species. Aphloia theiformis (Vahl) Benn.—C2, Cinnamomum verum J.Presl—C12, Ocimum gratissimum L.-C6, Plectranthus amboinicus (Lour.) Spreng.-C7, Cymbopogon nardus (L.) Rendle C4, Ocimum americanum L.-C5. 


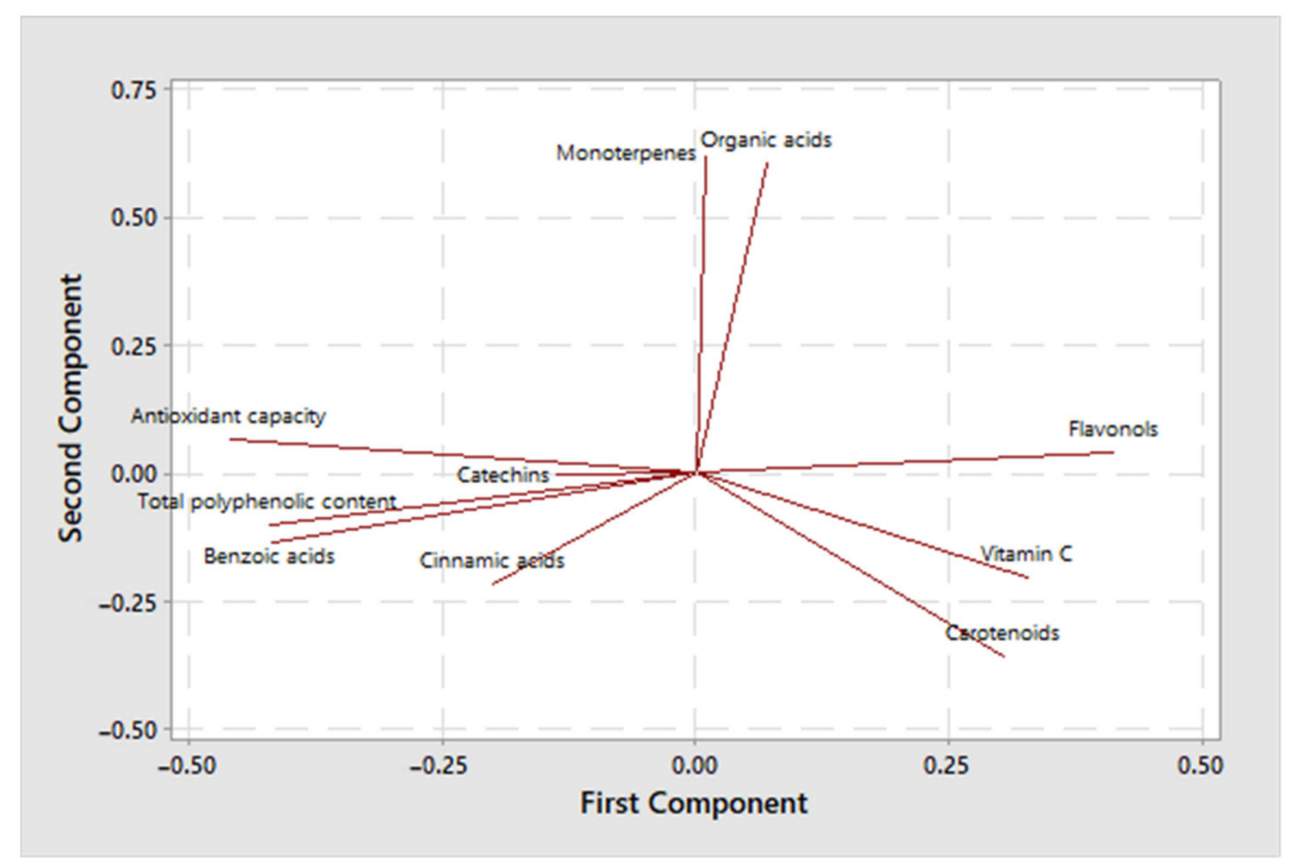

Figure 8. PCA loading plot of considered variables. In this case, the selected variables included the content of all the bioactive classes, TPC, and AOC.

The exploitation of natural resources, in particular medicinal plants, shows a strong relationship with the conservation of local biodiversity; moreover, the valorisation of these plants could increase the interest of local population to manage and protect the habitats; since the quantity of wild plants is continuously declining, a strong effort should be performed to develop new conservation strategies and policies. For this reason, this research provided a potential contribute to traditional Comorian foods and beverages and medicinal plants. Further phytochemical and biological studies will be very important to improve the information on botanical and food heritage of Comoros Islands.

\section{Conclusions}

In the Comoros Islands, many species containing health-promoting substances have not yet been studied. This preliminary study showed that Comorian tea is an important health-promoting beverage with many biologically active compounds and phytonutrients (e.g., phenolic acids, flavonols and monoterpenes). The applied approach allowed the identification and characterisation of the considered plants, even though further studies (e.g., mass spectrometry, NMR, IR, fluorescence) are necessary to better isolate, characterise, identify and quantify the effective value of biomolecules included in Comorian tea. Comorian tea may be used as a natural antioxidant dietary source to improve food quality in Comoros. Moreover, because of its high antioxidant properties, it could be considered as a health-promoting component to improve the diet of the local population. The analysed plants, thanks to their synergistic and additive effects, proved to be effective for maintaining good health status (high antioxidant capacity) according to the traditional use by the local Comorian population. For this reason, Comorian tea could be important in meeting the high demand in the Comoros Islands and other developing countries for cost-effective and natural health-promoting food and/or beverage to be produced by agri-food industries and used by the local population. Moreover, the valorisation of the considered plants (as a single component or mix) could provide an economic added value for Comoros development.

These results showed that it is very important to investigate the use of local biodiversity to produce traditional foods or beverages, suggesting the potential of phytochemical studies for biodiversity conservation, rural development, and sustainable use of natural 
resources. In any case, bioactivity and in vitro/in vivo toxicity studies using animal models are necessary because no scientific evidence is now available on the human safety of this beverage, even though it is widely used in Comorian folk food and medicine. A detailed approach should be applied to understand the effective health-promoting value of this traditional preparation in treating specific human diseases.

Supplementary Materials: The following are available online at https://www.mdpi.com/article/10 $.3390 /$ su13115815/s1, Table S1: Protocols for the extraction of bioactive compounds and nutritional substances, Table S2: Chromatographic conditions of the used HPLC methods.

Author Contributions: Conceptualization, D.D., S.H. and G.L.B.; methodology, D.D. and T.S.; validation, D.D.; formal analysis, D.D., G.G. and I.R.; investigation, D.D. and M.G.M.; resources, S.H. and T.S.; data curation, D.D. and M.G.M.; writing—original draft preparation, D.D.; writing—review and editing, D.D. and G.L.B.; supervision, G.L.B. and S.H. All authors have read and agreed to the published version of the manuscript.

Funding: This research received no external funding.

Institutional Review Board Statement: Not applicable.

Informed Consent Statement: Not applicable.

Data Availability Statement: Not applicable.

Acknowledgments: The authors thank the Coopérative et Mutuelle des Comores pour le Développement-CODCOM (Moroni, Comoros Islands), a Comorian non-governmental organization, for providing plant material.

Conflicts of Interest: The authors declare no conflict of interest.

\section{References}

1. Tombozara, N.; Donno, D.; Razafindrakoto, Z.R.; Randriamampionona, D.; Ramanitrahasimbola, D.; Andrianjara, C.; RamilisonRazafimahefa, R.D.; Rakotondramanana, D.A.; Beccaro, G.L. The first assessment on antioxidant and antidiabetic activities of leaves and stems of Vaccinium secundiflorum Hook. (Ericaceae), an endemic plant of Madagascar. South Afr. J. Bot. 2020, 130, 422-429. [CrossRef]

2. Singh, R. Medicinal plants: A review. J. Plant Sci. 2015, 3, 50.

3. Gurib-Fakim, A. Medicinal plants: Traditions of yesterday and drugs of tomorrow. Mol. Asp. Med. 2006, 27, 1-93. [CrossRef]

4. Rakotoniaina, N.E.; Donno, D.; Randriamampionona, D.; Harinarivo, H.L.; Andriamaniraka, H.; Solo, N.R.; Soifoini, T.; Torti, V.; Rabemanantsoa, C.; Andrianjara, C.; et al. Insights into an endemic medicinal plant species of Madagascar and Comoros: The case of Famelona (Chrysophyllum boivinianum (Pierre) Baehni, Sapotaceae family). South Afr. J. Bot. 2018, 117, 110-118. [CrossRef]

5. Gurib-Fakim, A.; Brendler, T. Medicinal and Aromatic Plants of Indian Ocean Islands: Madagascar, Comoros, Seychelles and Mascarenes; Medpharm: Guildford, UK, 2004.

6. Soifoini, T.; Donno, D.; Jeannoda, V.; Rakotoniaina, E.; Hamidou, S.; Achmet, S.M.; Solo, N.R.; Afraitane, K.; Giacoma, C.; Beccaro, G.L. Bioactive compounds, nutritional traits, and antioxidant properties of Artocarpus altilis (Parkinson) fruits: Exploiting a potential functional food for food security on the Comoros Islands. J. Food Qual. 2018. FirstOnline, In press. [CrossRef]

7. Mahamoudou, S.; Meritan, R. Agricultural intensification and agroforestry in the Comoros Islands. Cah. Agric. 1998, 7, 207-212.

8. Soidroua, S.H.; Mohamedb, N.A.; Faraha, A.; Said Hassane, S.O.; Bousta, D. Ethnopharmacoligical investigation of five plants used in Comorian folkloric medicine. Int. J. Phytopharm. 2013, 4, 230-236.

9. Beccaro, G.L.; Soifoini, T.; Donno, D.; Jeannoda, V.; Rakotoniaina, N.E.; Hamidou, S.; Achmet, S.M.; Afraitane, K.; Giacoma, C. Artocarpus altilis (Parkinson) Fosberg (breadfruit) nutritional characterization and local uses in Comoros Islands. Acta Hortic. 2020, 1267, 27-31. [CrossRef]

10. Soule, H.H.; Soidrou, S.H.; Farah, A.; Hassane, S.O.S.; Chaouch, A.; Lachkar, M. Ethnopharmacological investigation of four plants used as medicinal in Ngazidja Island. Int. J. Phytopharm. 2014, 5, 416-422.

11. Saive, M.; Frederich, M.; Fauconnier, M.-L.J.B. Agronomie, Société et Environnement. Plants used in traditional medicine in the Comoros archipelago: A review. Biotechnol. Agron. Soc. Environ. 2020, 24, 117-141. [CrossRef]

12. Hassani, M.S. Value addition to aromatic plants in Comoros. Asian Biotechnol. Dev. Rev. 2011, 13, $119-124$.

13. Kaou, A.M.; Mahiou-Leddet, V.; Mabrouki, F.; Hutter, S.; Laget, M.; Azas, N.; Yahaya, I.; Ollivier, E. Phytochemical study of plants used in traditional medicine in the treatment of malaria in the Comoros Islands. Planta Med. 2010, 76, P418.

14. Light, M.E. Medicinal and aromatic plants of Indian Ocean Islands: Madagascar, Comoros, Seychelles and Mascarenes. S. Afr. J. Bot. 2004, 70, 679. [CrossRef] 
15. Vos, P. Case studies on the status of invasive woody plant species in the western Indian Ocean. 2. The Comoros archipelago (Union of the Comoros aAnd Mayotte). For. Health Biosecurity Work. Pap. 2004, 4-2E vii, 34.

16. Walker, I. Ntsambu, the foul smell of home: Food, commensality and identity in the Comoros and in the diaspora. Food Foodways 2012, 20, 187-210. [CrossRef]

17. Bedigian, D. Handbook of African Medicinal Plants, 2nd ed.; CRC Press: Boca Raton, FL, USA, 2014; p. 1697.

18. United Nations. Comoros: Comprehensive Food Security and Vulnerability Analysis (CFSVA); United Nations World Food Programme: Rome, Italy, 2006.

19. Zielinski, A.A.F.; Haminiuk, C.W.I.; Alberti, A.; Nogueira, A.; Demiate, I.M.; Granato, D. A comparative study of the phenolic compounds and the in vitro antioxidant activity of different brazilian teas using multivariate statistical techniques. Food Res. Int. 2014, 60, 246-254. [CrossRef]

20. Mikus, M. Strategies, Meanings and Actor-Networks: Community-Based Biodiversity Conservation and Sustainable Development in the Comoros. MSc Anthropologiy and Development 2008, 2009. Available online: https://www.academia.edu/2827 02/Strategies_Meanings_and_Actor_Networks_Community_based_Biodiversity_Conservation_in_the_Comoros (accessed on 20 May 2021).

21. Lamuela-Raventós, R.M. Folin-Ciocalteu method for the measurement of total phenolic content and antioxidant capacity. In Measurement of Antioxidant Activity and Capacity: Recent Trends and Applications; Wiley: Hoboken, NJ, USA, 2018 ; p. 107.

22. Singleton, V.L.; Orthofer, R.; Lamuela-Raventos, R.M. Analysis of total phenols and other oxidation substrates and antioxidants by means of Folin-Ciocalteu reagent. Methods Enzymol. 1999, 299, 152-178.

23. Benzie, I.F.; Strain, J.J. Ferric reducing/antioxidant power assay: Direct measure of total antioxidant activity of biological fluids and modified version for simultaneous measurement of total antioxidant power and ascorbic acid concentration. Methods Enzymol. 1999, 299, 15-27.

24. Donno, D.; Mellano, M.G.; Riondato, I.; de Biaggi, M.; Andriamaniraka, H.; Gamba, G.; Beccaro, G.L. Traditional and unconventional dried fruit snacks as a source of health-promoting compounds. Antioxidants 2019, 8, 396. [CrossRef] [PubMed]

25. Mok, D.K.W.; Chau, F.T. Chemical information of chinese medicines: A challenge to chemist. Chemometrics Intell. Lab. Syst. 2006, 82, 210-217. [CrossRef]

26. Crawley, M. The $r$ Book, 2nd ed.; John Wiley \& Sons. Ltd: Chichester, UK, 2013.

27. Field, A. Discovering Statistics Using Ibm Spss Statistics; Sage: Newcastle upon Tyne, UK, 2013.

28. Dinç, I.; Sigdel, M.; Dinç, S.; Sigdel, M.S.; Pusey, M.L.; Aygün, R.S. Evaluation of Normalization and PCA on the Performance of Classifiers for Protein Crystallization Images; IEEE: New York, NY, USA, 2014.

29. Riondato, I.; Donno, D.; Roman, A.; Razafintsalama, V.E.; Petit, T.; Mellano, M.G.; Torti, V.; de Biaggi, M.; Rakotoniaina, E.N.; Giacoma, C.; et al. First ethnobotanical inventory and phytochemical analysis of plant species used by indigenous people living in the Maromizaha forest, Madagascar. J. Ethnopharmacol. 2019, 232, 73-89. [CrossRef]

30. Maulidiani; Abas, F.; Khatib, A.; Shaari, K.; Lajis, N.H. Chemical characterization and antioxidant activity of three medicinal Apiaceae species. Ind. Crop. Prod. 2014, 55, 238-247. [CrossRef]

31. Hassane, S.; Satrani, B.; Ghanmi, M.; Aafi, A.; Lachkar, M.; Chaouch, A. Chemical characterization and antioxidant effect of Ocimum basilicum L. Essential oil grown in comoros. Arab. J. Med. Aromat. Plants 2019, 5, 56-66.

32. Mathew, S.; Abraham, T.E. Studies on the antioxidant activities of cinnamon (Cinnamomum verum) bark extracts, through various in vitro models. Food Chem. 2006, 94, 520-528. [CrossRef]

33. Mattioni, C.; Martin, M.A.; Chiocchini, F.; Cherubini, M.; Gaudet, M.; Pollegioni, P.; Velichkov, I.; Jarman, R.; Chambers, F.M.; Paule, L.; et al. Landscape genetics structure of European sweet chestnut (Castanea sativa Mill): Indications for conservation priorities. Tree Genet. Genomes 2017, 13, 39. [CrossRef]

34. Donno, D.; Mellano, M.G.; Cerutti, A.K.; Beccaro, G.L. Nutraceuticals in alternative and underutilized fruits as functional food ingredients: Ancient species for new health needs. In Alternative and Replacement Foods; Academic Press: Cambridge, MA, USA, 2018; pp. 261-282.

35. Donno, D.; Mellano, M.; Hassani, S.; de Biaggi, M.; Riondato, I.; Gamba, G.; Giacoma, C.; Beccaro, G. Assessing nutritional traits and phytochemical composition of artisan jams produced in Comoros Islands: Using indigenous fruits with high health-impact as an example of biodiversity integration and food security in rural development. Molecules 2018, 23, 2707. [CrossRef]

36. López-Alarcón, C.; Denicola, A. Evaluating the antioxidant capacity of natural products: A review on chemical and cellular-based assays. Anal. Chim. Acta 2013, 763, 1-10. [CrossRef]

37. Soto-Vaca, A.; Gutierrez, A.; Losso, J.N.; Xu, Z.; Finley, J.W. Evolution of phenolic compounds from color and flavor problems to health benefits. J. Agric. Food Chem. 2012, 60, 6658-6677. [CrossRef] [PubMed]

38. Frijhoff, J.; Winyard, P.G.; Zarkovic, N.; Davies, S.S.; Stocker, R.; Cheng, D.; Knight, A.R.; Taylor, E.L.; Oettrich, J.; Ruskovska, T.; et al. Clinical relevance of biomarkers of oxidative stress. Antioxid. Redox Signal. 2015, 23, 1144-1170. [CrossRef]

39. Picot-Allain, M. Aphloia theiformis (Vahl.) Benn. A Plant with Various Therapeutic Properties. J. Soil Plant Biol. 2018, 1, 16-20.

40. Vieira, R.F.; Grayer, R.J.; Paton, A.J. Chemical profiling of Ocimum americanum using external flavonoids. Phytochemistry 2003, 63, 555-567. [CrossRef]

41. Donno, D.; Mellano, M.G.; de Biaggi, M.; Riondato, I.; Rakotoniaina, E.N.; Beccaro, G.L. New findings in Prunus padus L. fruits as a source of natural compounds: Characterization of metabolite profiles and preliminary evaluation of antioxidant activity. Molecules 2018, 23, 725. [CrossRef] [PubMed] 
42. Jonville, M.C.; Kodja, H.; Humeau, L.; Fournel, J.; de Mol, P.; Cao, M.; Angenot, L.; Frédérich, M. Screening of medicinal plants from Reunion island for antimalarial and cytotoxic activity. J. Ethnopharmacol. 2008, 120, 382-386. [CrossRef]

43. Matasyoh, L.G.; Matasyoh, J.C.; Wachira, F.N.; Kinyua, M.G.; Muigai, A.W.T.; Mukiama, T.K. Chemical composition and antimicrobial activity of the essential oil of Ocimum gratissimum L. growing in eastern Kenya. Afr. J. Biotechnol. 2007, 6. Available online: https:/ / www.ajol.info/index.php/ajb/article/view/56899 (accessed on 20 May 2020).

44. Dambolena, J.S.; Zunino, M.P.; López, A.G.; Rubinstein, H.R.; Zygadlo, J.A.; Mwangi, J.W.; Thoithi, G.N.; Kibwage, I.O.; Mwalukumbi, J.M.; Kariuki, S.T. Essential oils composition of Ocimum basilicum L. and Ocimum gratissimum L. from Kenya and their inhibitory effects on growth and fumonisin production by fusarium verticillioides. Innov. Food Sci. Emerg. Technol. 2010, 11, 410-414. [CrossRef]

45. Del Rio, D.; Rodriguez-Mateos, A.; Spencer, J.P.; Tognolini, M.; Borges, G.; Crozier, A. Dietary (poly) phenolics in human health: Structures, bioavailability, and evidence of protective effects against chronic diseases. Antioxid. Redox Signal. 2013, 18, 1818-1892. [CrossRef]

46. Razafindrakoto, Z.R.; Donno, D.; Tombozara, N.; Andriamaniraka, H.; Andrianjara, C.; Ramanitrahasimbola, D.; Beccaro, G.L. Antioxidant, anti-inflammatory, and antidiabetic activities of leaves and stems of Uapaca bojeri Bail.(Euphorbiaceae), an endemic plant of Madagascar. Pharmaceuticals 2020, 13, 71. [CrossRef] [PubMed]

47. Seeram, N.P. Berry fruits: Compositional elements, biochemical activities, and the impact of their intake on human health, performance, and disease. J. Agric. Food Chem. 2008, 56, 627-629. [CrossRef]

48. Silva, K.D.R.R.; Sirasa, M.S.F. Antioxidant properties of selected fruit cultivars grown in Sri Lanka. Food Chem. 2018, 238, 203-208. [CrossRef]

49. Landete, J.M. Ellagitannins, ellagic acid and their derived metabolites: A review about source, metabolism, functions and health. Food Res. Int. 2011, 44, 1150-1160. [CrossRef]

50. Papaefthimiou, D.; Papanikolaou, A.; Falara, V.; Givanoudi, S.; Kostas, S.; Kanellis, A.K. Genus cistus: A model for exploring labdane-type diterpenes' biosynthesis and a natural source of high value products with biological, aromatic, and pharmacological properties. Front. Chem. 2014, 2, 35. [CrossRef]

51. Trombetta, D.; Castelli, F.; Sarpietro, M.G.; Venuti, V.; Cristani, M.; Daniele, C.; Saija, A.; Mazzanti, G.; Bisignano, G. Mechanisms of antibacterial action of three monoterpenes. Antimicrob. Agents Chemother. 2005, 49, 2474-2478. [CrossRef] [PubMed]

52. Crowell, P.L. Prevention and therapy of cancer by dietary monoterpenes. J. Nutr. 1999, 129, 775S-778S. [CrossRef]

53. De Biaggi, M.; Donno, D.; Mellano, M.G.; Riondato, I.; Rakotoniaina, E.N.; Beccaro, G.L. Cornus mas (L.) fruit as a potential source of natural health-promoting compounds: Physico-chemical characterisation of bioactive components. Plant Food Hum. Nutr. 2018, 73, 89-94. [CrossRef]

54. Mahalwal, V.S.; Ali, M. Volatile constituents of Cymbopogon nardus (Linn.) Rendle. Flavour Fragr. J. 2003, 18, 73-76. [CrossRef]

55. Van Wyk, B.E. A broad review of commercially important southern African medicinal plants. J. Ethnopharmacol. 2008, 119, 342-355. [CrossRef]

56. Sen, T.; Samanta, S.K. Medicinal plants, human health and biodiversity: A broad review. In Biotechnological Applications of Biodiversity; Springer: Berlin, Germany, 2014; pp. 59-110.

57. Yamashita, S.; Sakane, T.; Harada, M.; Sugiura, N.; Koda, H.; Kiso, Y.; Sezaki, H.J. Absorption and metabolism of antioxidative polyphenolic compounds in red wine. Ann. N. Y. Acad. Sci. 2002, 957, 325-328. [CrossRef]

58. Van den Berg, A.; Halkes, S.; van Ufford, H.Q.; Hoekstra, M.; Beukelman, C.J. A novel formulation of metal ions and citric acid reduces reactive oxygen species in vitro. J. Wound Care 2003, 12, 413-418. [CrossRef] [PubMed]

59. Scalzo, R.L.J.F.C. Organic acids influence on DPPH scavenging by ascorbic acid. Elsevier 2008, 107, 40-43. [CrossRef]

60. Chetia, J.; Upadhyaya, S.; Saikia, L.J. Phytochemical analysis, antioxidant and antimicrobial activity and nutrient content analysis of Ocimum gratissimum Linn. from Dibrugarh, Ne India. Chemistry 2014, 25, 229.

61. Vij, L. Effect of Coloured Nets on Growth and Biochemical Components in Different Species of Ocimum; Punjab Agricultural University: Ludhiana, India, 2020.

62. Müller, L.; Caris-Veyrat, C.; Lowe, G.; Böhm, V. Lycopene and its antioxidant role in the prevention of cardiovascular diseases-A critical review. Crit. Rev. Food Sci. Nutr. 2016, 56, 1868-1879. [CrossRef]

63. Rawson, A.; Patras, A.; Tiwari, B.K.; Noci, F.; Koutchma, T.; Brunton, N. Effect of thermal and non thermal processing technologies on the bioactive content of exotic fruits and their products: Review of recent advances. Food Res. Int. 2011, 44, $1875-1887$. [CrossRef]

64. Skibsted, L.H. Carotenoids in antioxidant networks. Colorants or radical scavengers. J. Agric. Food Chem. 2012, 60, 2409-2417. [CrossRef]

65. Stephensen, C.B. Provitamin a carotenoids and immune function. In Carotenoids and Human Health; Springer: Berlin, Germany, 2013; pp. 261-270.

66. Sharoni, Y.; Linnewiel-Hermoni, K.; Khanin, M.; Salman, H.; Veprik, A.; Danilenko, M.; Levy, J. Carotenoids and apocarotenoids in cellular signaling related to cancer: A review. J. Mol. Nutr. Food Res. Int. 2012, 56, 259-269. [CrossRef]

67. Saini, R.K.; Nile, S.H.; Park, S.W. Carotenoids from fruits and vegetables: Chemistry, analysis, occurrence, bioavailability and biological activities. Food Res. Int. 2015, 76, 735-750. [CrossRef] [PubMed]

68. Nicoletti, M. Nutraceuticals and botanicals: Overview and perspectives. Int. J. Food Sci. Nutr. 2012, 63, 2-6. [CrossRef] 
69. Donno, D.; Boggia, R.; Zunin, P.; Cerutti, A.K.; Guido, M.; Mellano, M.G.; Prgomet, Z.; Beccaro, G.L. Phytochemical fingerprint and chemometrics for natural food preparation pattern recognition: An innovative technique in food supplement quality control. J. Food Sci. Technol. 2016, 53, 1071-1083. [CrossRef]

70. Turrini, F.; Donno, D.; Boggia, R.; Beccaro, G.L.; Zunin, P.; Leardi, R.; Pittaluga, A.M. An innovative green extraction and re-use strategy to valorize food supplement by-products: Castanea sativa bud preparations as case study. Food Res. Int. 2019, 115, 276-282. [CrossRef] 